\title{
Hedgehog Signaling in the Subventricular Zone Is Required for Both the Maintenance of Stem Cells and the Migration of Newborn Neurons
}

\author{
Francesca Balordi and Gord Fishell \\ Smilow Neuroscience Program and the Department of Cell Biology, Smilow Research Center, New York University School of Medicine, New York, \\ New York 10016
}

We examined the postnatal consequences of removing Hedgehog signaling within the adult stem cell niche. Although at birth the subventricular zone appears normal in mice lacking Hedgehog signaling, by postnatal day 8 it is greatly impaired, and cell death is increased. In addition, both the quiescent $B$ stem cell population and transit-amplifying $C$ cells become depleted postnatally. In contrast, the A cell population expands precociously, mostly fails to migrate to the olfactory bulbs, and is ultimately also depleted by postnatal day 30. In vitro and in vivo analyses demonstrate that this failure in migration is a result of nonautonomous signaling, possibly caused by a reduction in Slit1 ligand in A cells. These results suggest that Hedgehog signaling is required for the maintenance of the B and C cell populations and indirectly for the migration of the neurons that are generated from the adult stem cell niche.

Key words: Hh signaling; stem cells; niche; subventricular zone; proliferation; migration

\section{Introduction}

Hedgehog (Hh) plays numerous iterative roles during embryonic development (Ingham and McMahon, 2001; McMahon et al., 2003). In particular, Hh is essential for early ventral telencephalic patterning (Echelard et al., 1993; Ericson et al., 1995; Marti et al., 1995; Chiang et al., 1996; Kohtz et al., 1998; Rallu et al., 2002; Fuccillo et al., 2004) and proliferation (Dahmane and Ruiz i Altaba, 1999; Rowitch et al., 1999; Wallace, 1999; Wechsler-Reya and Scott, 1999; Britto et al., 2002). Work from our laboratory (Machold et al., 2003) and others (Lai et al., 2003) has suggested a mitogenic role for Hh signaling. Recent work has indicated that Hh signaling is also used in the quiescent stem cell population (Ahn and Joyner, 2005). Here, we have examined the precise stages of the stem cell lineage that require this signaling pathway.

Hh signaling in mammals relies on the transmembrane protein Smoothened (Smo) (Zhang et al., 2001). Our previous study (Machold et al., 2003) made use of a conditional null Smo allele $\left(S m o^{c / c}\right)$, in conjunction with a Nestin-Cre driver mouse line $\left(\mathrm{Nestin}^{\mathrm{Cre} /+}\right)$. Notably, development in the telencephalon appears to be essentially normal until birth (Machold et al., 2003). In contrast, by postnatal day 15 (P15), the level of proliferation in the subventricular zone (SVZ) of mutant animals is markedly

\footnotetext{
Received July 14, 2006; revised April 20, 2007; accepted April 24, 2007.

We thank the entire Fishell laboratory for critical reading of this manuscript as well as helpful comments. We are grateful to Andrew P. McMahon for the Smo ${ }^{c}$ allele, Stewart A. Anderson for the Nestin ${ }^{\text {Cre }}$ allele, and A. Joyner for the Gli $^{\text {LacZ }}$ allele. We thank the following people for their gifts of cDNA probes: A. Joyner (Gli1), F. Guillemot (Mash1), J. Rubenstein (D/x2), and D. Ginty (Slit1). We thank J. Kohtz for the pan-Dlx antibody.

Correspondence should be addressed to Gord Fishell, Smilow Neuroscience Program and the Department of Cell Biology, Smilow Research Center, New York University School of Medicine, 522 First Avenue, New York, NY 10016. E-mail: fishell@saturn.med.nyu.edu.

DOI:10.1523/JNEUROSCI.1040-07.2007

Copyright $\odot 2007$ Society for Neuroscience $\quad$ 0270-6474/07/275936-12\$15.00/0
}

decreased, whereas cell death is dramatically increased (Machold et al., 2003).

We now examine how the loss of Hh signaling affects the lineage progression of cells within the SVZ niche. In this region, periventricular slow-dividing GFAP + (B) cells have been shown to be the stem cell population (Doetsch et al., 1997, 1999a,b, 2002). After activation, $B$ cells generate a transit-amplifying $C$ cell population that in turn gives rise to new neuroblasts (A cells). Work from a recent study (Ahn and Joyner, 2005) showed that quiescent adult neural stem cells and at least a portion of transitamplifying cells are $\mathrm{Hh}$ responsive.

Here, we analyzed the SVZ of $\mathrm{Nestin}^{\mathrm{Cre} /+} ; \mathrm{Smo}^{c / c}$ mutants at a series of time points between $\mathrm{P} 0$ and $\mathrm{P} 30$. Although the SVZ of P0 mutants was not affected, by P8 there was a significant reduction in proliferation and a marked increase in cell death in the SVZ. In mutant mice, we observed a depletion of both quiescent stem cells and transit-amplifying cells, coupled with massive overproduction of A cells at P8. These A cells fail to migrate, accumulate in the striatocortical angle, and undergo apoptosis. In vitro and in vivo analyses suggest that the failure in migration is a nonautonomous result of the loss of Hedgehog signaling. These data suggest that Hh signaling, in the postnatal forebrain, has a role in controlling the progressive transitions from quiescent stem cell to newborn neurons. Although Hh signaling acts to keep the stem cells in a quiescent state, it is required for the proliferation of the $\mathrm{C}$ cells and the survival and migration of the A cell population. Thus, Hh signaling subserves distinct and diverse functions in the sublineages that comprise the stem cell niche.

\section{Materials and Methods}

Mice breedings. All mice used in these studies were maintained according to protocols approved by the Institutional Animal Care and Use Com- 
mittee at New York University School of Medicine. Conditional (floxed) Smo mice $\left(\mathrm{Smo}^{c / c}\right)$ were a gift from Andrew McMahon and were genotyped as described previously (Lewis et al., 2001; Long et al., 2001). Mutant mice $\left(\mathrm{Nestin}^{\mathrm{Cre} /+} ; \mathrm{Smo}^{c / c}\right)$ were obtained by crossing homozygous conditional Smo mice $\left(\mathrm{Smo}^{c / c}\right)$ with mice heterozygous for conditional Smo and Nestin ${ }^{\mathrm{Cre}}\left(\mathrm{Nestin}^{\mathrm{Cre} /+} ; \mathrm{Smo}^{c /+}\right)$. The Nestin ${ }^{\mathrm{Cre}}$ allele used (Tronche et al., 1999; Graus-Porta et al., 2001) for directing removal of Smo expresses the Cre recombinase from the neural specific enhancer of the Nestin promoter (Zimmerman et al., 1994). Interestingly, compared with our previous study (Machold et al., 2003), we were able to achieve longer survival of Smo conditional mutants by using $S m o^{c / c}$ rather than $\mathrm{Smo}^{c /-}$ mice crossed to the driver line Nestin ${ }^{\mathrm{Cr}}$.

Reporter strain used. Heterozygous Gli1 ${ }^{\text {LacZ }}$ (gift from A. Joyner) (Bai et al., 2002) mice were used to perform double labeling on perinatal (P8) and adult (P30) mice using $\beta$-galactosidase ( $\beta$-gal) antibody and the panel of molecular markers characteristic of the different populations of the SVZ stem cell niche.

Tissue preparation. All mice were overdosed with anesthetic and transcardially perfused. Brains were removed and postfixed with $4 \%$ paraformaldehyde (PFA) in PBS. For frozen sections (12-20 $\mu \mathrm{m})$, brains were washed in PBS, cryoprotected in 30\% sucrose, embedded in Tissue-Tek (VWR, West Chester, PA) on dry ice, and cut on a Zeiss (Thornwood, NY) HM500 OM cryostat. For free-floating sections $(80 \mu \mathrm{m})$, brains were washed in PBS and cut on a Leica (Bannockburn, IL) Vibratome 1000 S.

Bromodeoxyuridine administration. For the bromodeoxyuridine (BrdU) pulse-kill experiment, mice were injected once with BrdU (100 $\mathrm{mg} / \mathrm{g}$ of body weight, i.p.; Sigma-Aldrich, St. Louis, MO) $1 \mathrm{~h}$ before they were killed. For long-term BrdU administration, BrdU ( $1 \mathrm{mg} / \mathrm{ml}$; SigmaAldrich) was given to mice in their drinking water for $14 \mathrm{~d}$, and they were killed $12 \mathrm{~d}$ later.

Immunocytochemistry. Vibratome or cryostat sections were stained with the following primary antibodies: rabbit $\alpha$-brain lipid-binding protein (BLBP) (1:2000; Millipore, Billerica, MA), rabbit $\alpha$-GFAP (1:2000; Accurate Chemical, Westbury, NY), rat $\alpha$-GFAP (1:500; Zymed Laboratories, South San Francisco, CA), mouse $\alpha$-BrdU (1:100; BD Biosciences, San Jose, CA), rat $\alpha$-BrdU (1:50; AbD Serotec, Raleigh, NC), rabbit $\alpha$-caspase-3 (1:200; Cell Signaling Technology, Beverly, MA), mouse $\alpha$ - $\beta$-galactosidase (1:1000; Promega, Madison, WI), rabbit $\alpha$ - $\beta$ galactosidase (1:1000; MP Biomedicals, Solon, OH), mouse $\alpha$-mammalian achaete-scute homolog 1 (Mash1; 1:500; BD Biosciences), goat $\alpha$-doublecortin (C-18; 1:1000; Santa Cruz Biotechnology, Santa Cruz, CA), rabbit $\alpha$-pan-Dlx (1:100; gift from J. Kohtz, Northwestern University, Chicago, IL), rabbit $\alpha$-S-100 $\beta$ (1:2000; Dako, High Wycombe, UK), rat $\alpha$-mCD24 (1:500; BD Biosciences). Secondary antibodies, raised in donkey, used at 1:1000 (Alexa 594 and Alexa 488) were obtained from Invitrogen (Eugene, OR). Standard immunocytochemical staining procedures were used. For BrdU staining, sections were treated with $1 \mathrm{~N} \mathrm{HCl}$ for $15 \mathrm{~min}$ at $55^{\circ} \mathrm{C}$, washed with PBS, treated with proteinase $\mathrm{K}$ for $10 \mathrm{~min}$ at $37^{\circ} \mathrm{C}$, washed with PBS, postfixed with $4 \%$ PFA for 10 min at room temperature (RT), and washed with PBS, before proceeding to the blocking step.

Fluorescent images were obtained using an Axioplan (Zeiss) and MetaMorph software (Universal Imaging, Downingtown, PA). Confocal imaging was done on an LSM 510 Axioplan 2 Imaging microscope (Zeiss). Optical sections were taken every $1 \mu \mathrm{m}$.

In situ hybridization. mRNA in situ hybridizations was performed as described previously (Wilkinson and Nieto, 1993). RNA probes were labeled with digoxigenin and visualized with BM-Purple, according to the manufacturer's instruction (Roche Biosciences, Palo Alto, CA). The cRNA probes used included Smo, Gli1 (Kinzler et al., 1988), Mash1 (Cau et al., 1997), Dlx2 (Bulfone et al., 1993), and Slit1 (Yuan et al., 1999). To generate Smo probes, we linearized the IMAGE EST clone (5716021; Invitrogen) with SalI and used T3 RNA polymerase to obtain antisense probe; alternatively, we linearized with NotI and used T7 RNA polymerase to obtain sense probe. Images were obtained by bright-field photography on a Zeiss Axioskop using Spot Advanced software.

$\beta$-gal staining. Tissue sections were stained for $\beta$-galactosidase histochemistry using a solution containing $0.1 \mathrm{M}$ phosphate buffer, $2 \mathrm{~mm}$
$\mathrm{MgCl}_{2}, 0.01 \%$ sodium deoxycholate, $0.02 \% \mathrm{NP}-40,5 \mathrm{~mm} \mathrm{~K}{ }_{3} \mathrm{Fe}(\mathrm{CN})_{6}, 5$ $\mathrm{mM} \mathrm{K}_{4} \mathrm{Fe}(\mathrm{CN})_{6}$, and $1 \mathrm{mg} / \mathrm{ml} \mathrm{X}$-gal (5-(bromo-4-chloro-3-indolyl- $\beta$-Dgalactopyranoside; Fisher Scientific, Hampton, NH) at RT overnight. Stained tissue sections were then washed in PBS, counterstained with Fast Red, dehydrated, and coverslipped with Permount before brightfield photography on a Zeiss Axioskop.

Cultures of SVZ in Matrigel. Brains from P8 mutant animals $\left(\mathrm{Nestin}^{\mathrm{Cre} /+} ; \mathrm{Smo}^{c / c}\right)$ and littermate controls $\left(\mathrm{Smo}^{c /+}\right.$ and $\left.\mathrm{Smo} \mathrm{c}^{c / c}\right)$ were placed in ice-cold Leibovitz's L-15 medium (Invitrogen). The SVZ from the lateral wall of the lateral ventricle was dissected and cut into pieces $50-300 \mu \mathrm{m}$ in diameter. The explants were transferred in serum-free Neurobasal medium (Invitrogen) containing B-27 supplement (Invitrogen), $0.5 \mathrm{~mm}$ L-glutamine (Invitrogen), and penicillin-streptomycin antibiotics (Invitrogen), mixed with Matrigel Basement Membrane Matrix (BD Biosciences) in a 1:1 ratio and allowed to congeal in a $35 \mathrm{~mm}$ tissue culture dish. The gel containing the explant was overlaid with $2 \mathrm{ml}$ of Neurobasal medium. Culture were maintained in a humidified, $5 \% \mathrm{CO}_{2}$, $37^{\circ} \mathrm{C}$ incubator (Heraeus, Werheim, Germany) for $3 \mathrm{~d}$. The explants were fixed with $4 \%$ PFA, washed with PBS, and immunostained for Doublecortin (Dcx) and GFAP.

Transplants. Donor cells were dissected from the SVZ of the lateral ventricle of P8 $\beta$-actin ${ }^{\text {EGFP/+ }}$ (Okabe et al., 1997) or Nestin ${ }^{\mathrm{Cre} /+}$;Smo ${ }^{c / c}$; $\beta$-actin ${ }^{E G F P /+}$ pups, under a dissecting scope. The collected tissue blocks were dissociated to a single-cell suspension using the papain dissociation kit (Worthington Biochemical, Lakewood, NJ) and resuspended at a final concentration of 50,000 cells/ $\mu \mathrm{l}$ in DMEM/F12 medium. The recipient pups [P8 wild-type (wt) or Nestin $\left.{ }^{\mathrm{Cre} /+} ; \mathrm{Smo}^{c / c}\right]$ were cryoanesthetized for $2 \mathrm{~min}$, and the skull was exposed by a skin incision overlaying the forebrain using a surgical blade. The pup was placed in a self-made mold for stabilization, and $2 \mu \mathrm{l}$ of the cell suspension was bilaterally injected into the SVZ with the help of a Hamilton syringe mounted vertically into a stereotaxic holder, at the following stereotaxic coordinates: anterior, 0.5 $\mathrm{mm}$; lateral, $1 \mathrm{~mm}$; depth, $1.5 \mathrm{~mm}$ (relative to bregma and the surface of the brain). The incision was sealed with Vetbond, and the animals were then warmed to $36^{\circ} \mathrm{C}$ and returned to the litter. One week after transplantation, the animals were perfused for histological analyses.

Quantitation. Using MetaMorph software (Universal Imaging), the SVZ was outlined and the number of BrdU-, caspase-3-, or Mash1positive cells was counted. Three to 12 sections were analyzed per animal with a minimum of three animals per time point. For quantitation of migration in transplanted mice, the number of GFP + cells that reached the olfactory bulb (OB) was counted. Microsoft (Seattle, WA) Excel was used to compute the data and perform the statistical analyses. ANOVA analysis was performed using the software provided at www.physics.csbsju.edu/stats/anova.html.

Supplemental data. Supplemental data include one table and five figures, available at www.jneurosci.org as supplemental material.

\section{Results \\ Proliferation and cell death in wild-type versus $\mathrm{Nestin}^{\mathrm{Cre} /+}$; $S m o^{c / c} S V Z$}

To determine the phenotypes resulting from the loss of Hh signaling within the SVZ, we examined its effects on lineages within this stem cell niche. To evaluate the progression of defects in the niche of $\mathrm{Nestin}^{\mathrm{Cre} /+} ; \mathrm{Smo}^{c / c}$ mutants, we analyzed proliferation and cell death in the mutant versus wild-type SVZ at P0, P8, P15, and P30. We chose these time points to cover the lifespan of these mutant mice, which is in most cases $\sim 1$ month. To assess the general level of proliferation in the SVZ, we administered BrdU $1 \mathrm{~h}$ before killing the mice. We also immunostained for cleaved caspase-3, a marker of apoptosis, to examine the extent of cell death in these mutants.

\section{By $\mathrm{P8}$, Hh signaling is required for maintenance of the SVZ stem cells}

As expected, we observed that Hh signaling, examined by both Smo and Gli1 (a direct readout of Hh signaling) (Lee et al., 1997) 
expression, was completely absent in Nestin ${ }^{\mathrm{Cr} /+} ; \mathrm{Smo}^{c / c}$ mutants at $\mathrm{P} 0$ and thereafter (supplemental Fig. S1, available at www.jneurosci.org as supplemental material). At P0, the labeling resulting from a $1 \mathrm{~h}$ pulse of BrdU before the mice were killed was equivalent in mutant and control pups (Fig. $1 a-d$ ). In contrast, at older ages we observed a progressive decrease in proliferation in the mutants. In the SVZ of P8 Nestin ${ }^{\mathrm{Cre} /+} ; \mathrm{Smo}^{c / c}$ mutant animals, we observed a $50 \%$ reduction in proliferation compared with controls (Fig. $1 e-h$ ). Continuing this pattern, at P15 proliferation was reduced to $40 \%$ of that seen in control animals (Fig. $1 i-l$ ) and was further decreased to $36 \%$ of controls by P30 (Fig. $1 m-p$ ). Other postnatal defects typical of these mutants are the enlargement of the telencephalic ventricles and a $30 \%$ reduction in brain size (reported previously by Machold et al., 2003).

Accompanying this decline in proliferation, we observed a considerable amount of cell death in mutant animals. Although very little cell death was seen in the SVZ of $\mathrm{Nestin}^{\mathrm{Cre} /+} ; \mathrm{Smo}^{c / c}$ mutant animals at birth (Fig. $2 a-d$ ), by $\mathrm{P} 8$ there was a marked (eightfold) increase in cell death compared with controls (Fig. $2 e-h$ ). Interestingly, despite the fact that the SVZ niche extends throughout the lateral wall of the lateral ventricle, the vast majority of cell death observed was confined to the striatocortical angle, a region situated at the pallial/subpallial boundary, at which a large proportion of transit-amplifying cells and newborn neurons normally reside. In contrast to the trend we saw with regard to proliferation, cell death in the SVZ of the mutants actually diminished with age. At P15, the apoptosis in the mutant SVZ was four times higher than controls (Fig. $2 i-l$ ), but by P30, cell death was only 1.6-fold greater than that seen in the SVZ of wild-type animals (Fig. $2 m-p$ ). However, the reduction in cell death at P30 may simply reflect a depletion of the stem cell niche by this time point (see below).

Mice carrying the $S m o^{c / c}$ or the $S m o^{c /+}$ alleles showed an increased level of cell death in the SVZ compared with wild types, suggesting both that this allele is hypomorphic and that Hh-dependent cell survival is dose dependent (Fig. 2q). The fact that the floxed Smo allele is not fully functional is perhaps attributable to the presence of a cassette containing neo and $\mathrm{LacZ}$ in the first intron (although we cannot detect lac $Z$ expression). For this reason, in our analysis, we consistently exam-

\section{BrdU}
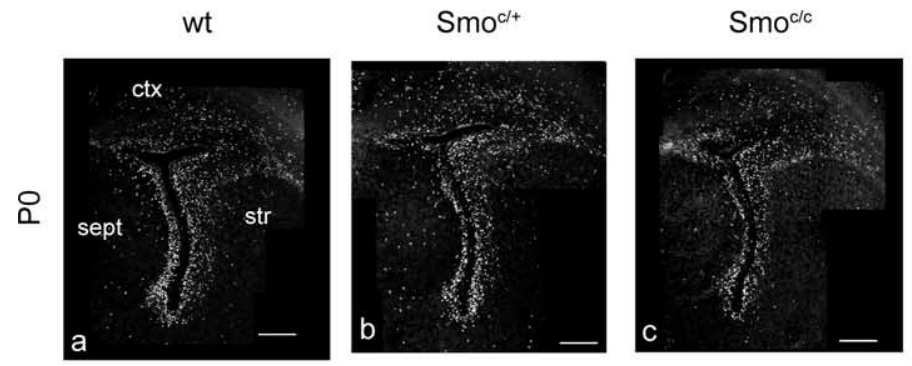

Nestin ${ }^{\mathrm{Cre} /+} ; \mathrm{Smo} / \mathrm{c}$
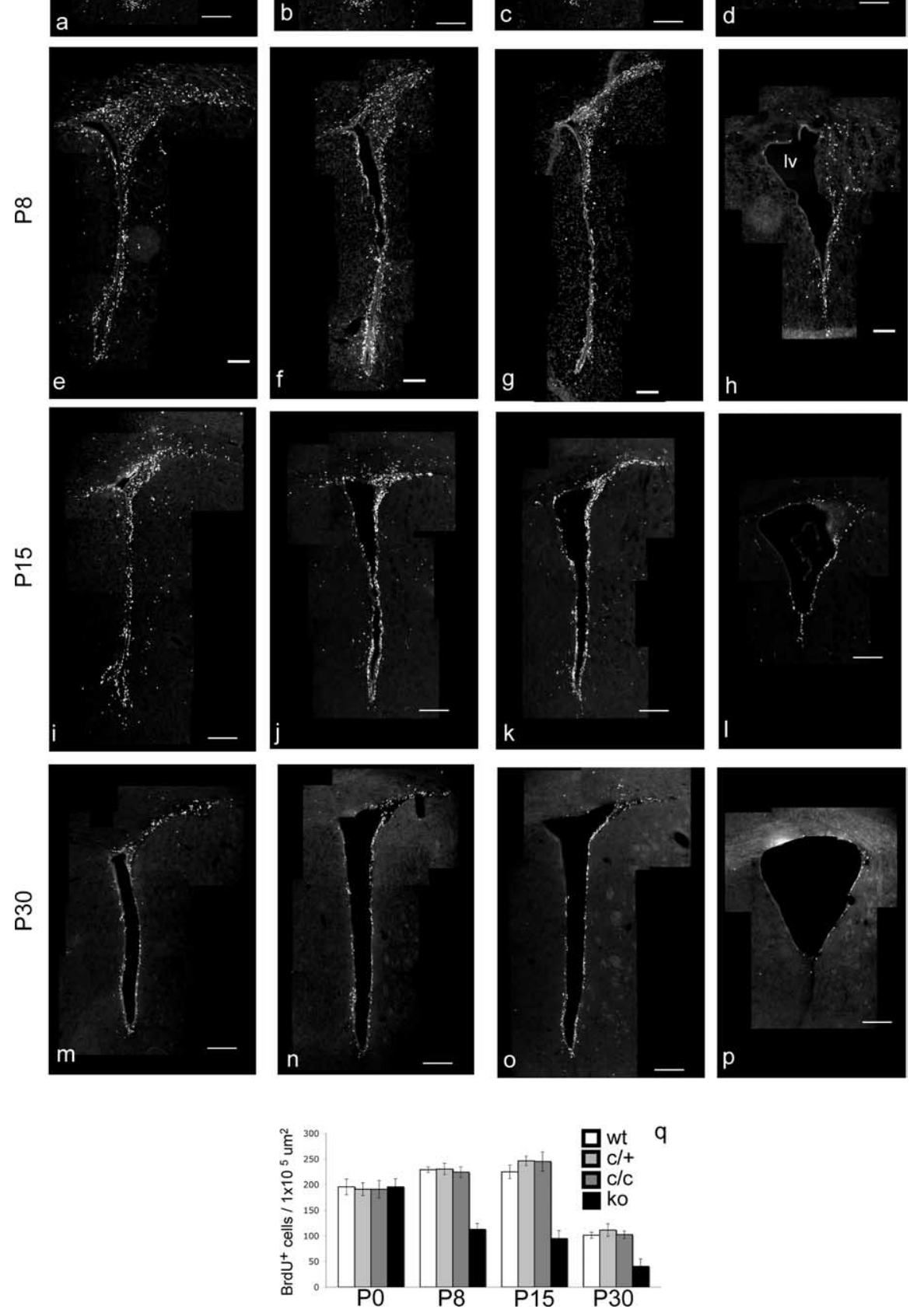

Figure 1. The general level of proliferation is strongly reduced in the SVZ of perinatal conditional Smoothened-null mice from P8 onward. $\boldsymbol{a}-\boldsymbol{p}$, Coronal views of the whole SVZ showing BrdU-incorporating cells in wild-type $(\boldsymbol{a}, \boldsymbol{e}, \boldsymbol{i}, \boldsymbol{m}), \operatorname{Smo}^{\boldsymbol{c l +}}(\boldsymbol{b}, \boldsymbol{f}, \boldsymbol{j}, \boldsymbol{n})$,

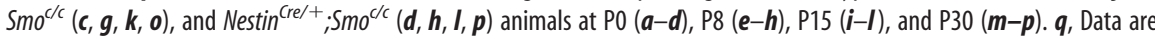
quantitated. ctx, Cortex; str, striatum; sept, septum; Iv, lateral ventricle; ko, knock-out. Scale bars: $\boldsymbol{e}-\boldsymbol{h}, 100 \mu \mathrm{m} ; \boldsymbol{a}-\boldsymbol{d}, \boldsymbol{i}-\boldsymbol{p}, 200$ $\mu \mathrm{m}$. Error bars represent SD. Statistics were performed by ANOVA; at P0, $p=0.94$; at other ages, $p<0.0001$. 

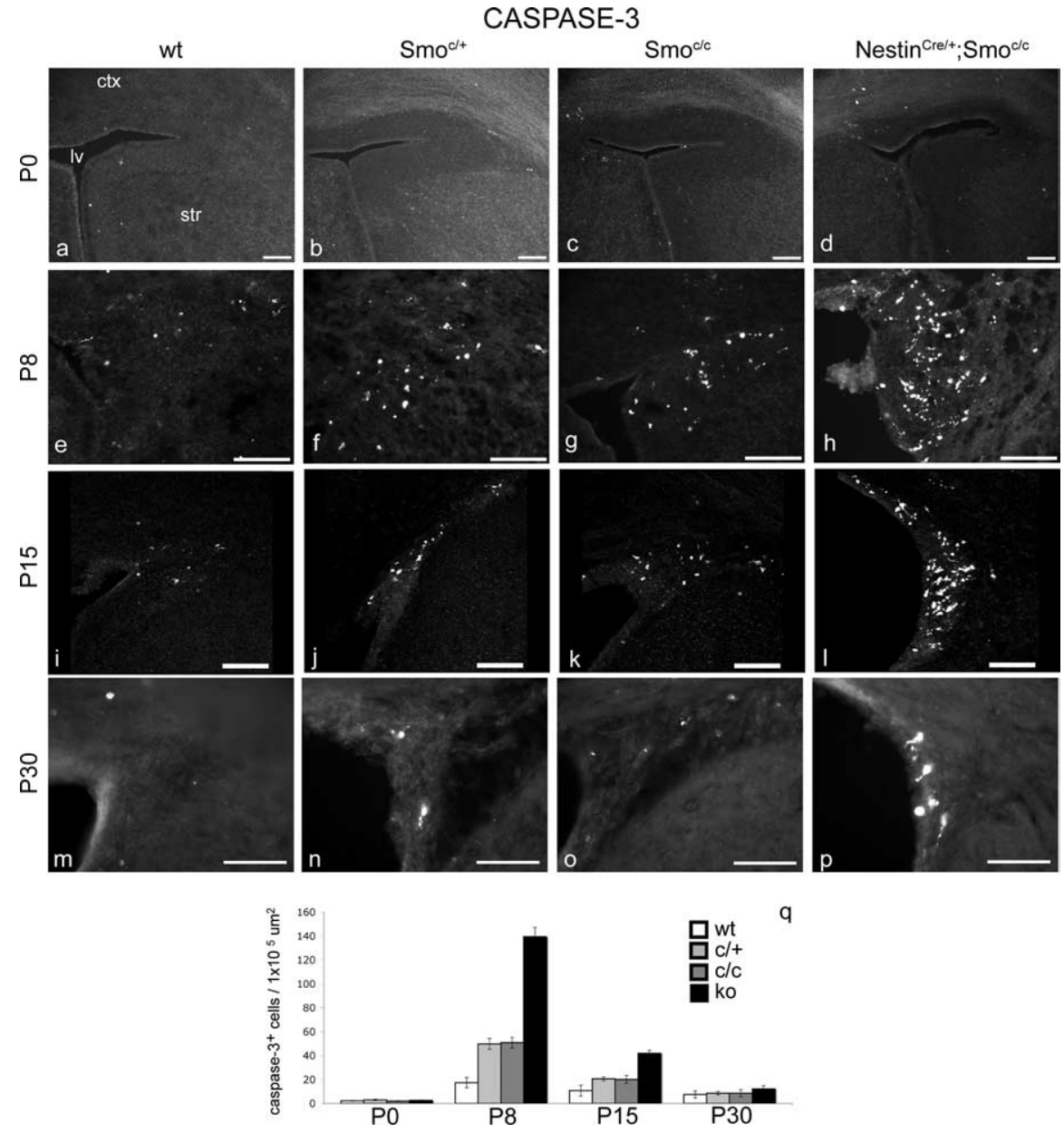

Figure 2. Cell death is detected in the SVZ of perinatal conditional Smoothened-null mice from P8 onward. Mice carrying one or two copies of the Smo allele show an intermediate level of cell death between that observed in wild-type mice and $\mathrm{Nestin}^{\mathrm{Cre} /+}$, $S m 0^{c / c}$ mutants. $\boldsymbol{a}-\boldsymbol{p}$, Coronal views of the striatocortical angle of the SVZ showing cleaved-caspase-3 immunocytochemical staining in wild-type $(\boldsymbol{a}, \boldsymbol{e}, \boldsymbol{i}, \boldsymbol{m}), \mathrm{Smo}^{c /+}(\boldsymbol{b}, \boldsymbol{f}, \boldsymbol{j}, \boldsymbol{n}), \operatorname{Smo}^{c / c}(\boldsymbol{c}, \boldsymbol{g}, \boldsymbol{k}, \boldsymbol{o})$, and Nestin ${ }^{\mathrm{Cre} /+} ; \operatorname{Smo}^{c / c}(\boldsymbol{d}, \boldsymbol{h}, \boldsymbol{l}, \boldsymbol{p})$ animals at PO $(\boldsymbol{a}-\boldsymbol{d}), \mathrm{P} 8$ $(\boldsymbol{e}-\boldsymbol{h}), \mathrm{P} 15(\boldsymbol{i}-\boldsymbol{l})$, and P30 ( $\boldsymbol{m}-\boldsymbol{p}) . \boldsymbol{q}$, Data are quantitated. ctx, Cortex; str, striatum; Iv, lateral ventricle; ko, knock-out. Scale bars, $100 \mu \mathrm{m}$. Error bars represent SD. Statistics were performed by ANOVA; at P30, $p=0.0002$; at other ages, $p<0.0001$.

population, we also undertook a BrdU pulse-chase experiment to evaluate the status of the B cell population at P30 in wild-type and Nestin ${ }^{\mathrm{Cre} /+} ; \mathrm{Smo}^{c / c} \mathrm{SVZ}$.

$B$ and $C$ cells are Hedgehog responsive A previous study demonstrated that B and $\mathrm{C}$ cells are $\mathrm{Hh}$ responsive based on their expression of Gli1 (Ahn and Joyner, 2005). We confirmed these results using the same approach. We therefore took advantage of the Gli1 ${ }^{\text {LacZ }}$ knock-in allele (Bai et al., 2002; Ahn and Joyner, 2005), in which the expression of LacZ provides a direct readout of Hh signaling. Using these mice, we compared the localization of nuclear LacZ to GFAP, a known marker of B cells (Doetsch et al., 1997, 1999a,b, 2002). In addition, we examined BLBP, a protein that previous work revealed to be a marker of neurogenic radial glia (Anthony et al., 2004). We reasoned that BLBP might be a marker of the adult stem cell population. In line with this notion, we observed substantial overlap between GFAP and BLBP in the periventricular region (supplemental Fig. S2a,b, available at www. jneurosci.org as supplemental material). In addition, we also observed that the majority of both GFAP and BLBP cells in this region colocalized with Gli1 expression, as assessed by LacZ staining in Gli1 ${ }^{\mathrm{LacZ} /+}$ knock-in mice (supplemental Fig. S2d,e, available at www.jneurosci.org as supplemental material). Hence, consistent with the previous results of other groups (Ahn and Joyner, 2005; Palma et al., 2005), we found that the majority of $\mathrm{B}$ cells in the ventral part of the SVZ appears to be responding to Hh signaling.

ined three different controls: wt, $S m o^{c /+}$, and $S m o^{c / c}$. Despite this concern, in all other contexts we examined (e.g., with regard to the numbers of B, C, and A cells in the niche), $S m o^{c /+}, S m o^{c / c}$, and wt alleles were indistinguishable (see supplemental Fig. S5, available at www.jneurosci.org as supplemental material, and quantitations in Figs. 1q, 4d).

\section{The effect of the loss of Hh signaling on different cell types within the SVZ stem cell lineage}

Based on our analysis of proliferation and cell death, we focused on additional analysis of P8 and later time points to determine how the loss of Hh signaling in the postnatal SVZ affects the lineage progression from $\mathrm{B}$ stem cells to transit-amplifying $\mathrm{C}$ cells, ultimately resulting in the generation of nascent A neurons. To directly examine each of these populations, we used a panel of molecular markers [GFAP and BLBP for B cells; Mash1 for C cells; Dlx for A and C cells; Dcx for A cells alone; S100- $\beta$ and mCD24 for E cells (see supplemental Table S1, available at www.jneurosci.org as supplemental material)]. Although the markers for $\mathrm{C}$ and A cells readily allow them to be distinguished from other populations, both GFAP and BLBP are widely expressed in other cells in addition to the B cell population. To definitively identify the slow-dividing stem cell
To confirm that a subpopulation of transit-amplifying cells responds to Hh (Ahn and Joyner, 2005), we examined whether Mash1-positive C cells (Parras et al., 2004) colabel with Gli1, and we found that a small cohort of Mash1-positive cells were Gli1 positive, as indicated by their expression of $\mathrm{LacZ}$ in $\mathrm{Gli1}^{\mathrm{LacZ} /+}$ knock-in mice (supplemental Fig. S2 $f$, available at www. jneurosci.org as supplemental material). We also found that both ependymal cells (E cells) and neuroblasts (A cells) are Gli1 negative (supplemental Fig. S2 $g, h$, available at www.jneurosci.org as supplemental material).

\section{By P30, B cells appear affected in conditional Smoothened-null mice}

Given the evidence of active Hh signaling in B cells, we expected that this population would be affected by the loss of $\mathrm{Hh}$ signaling. To our surprise, immunocytochemical analysis of $\mathrm{Nestin}^{\mathrm{Cre} /+}$; $\mathrm{Smo}^{c / c}$ mutants revealed no obvious change of GFAP or BLBPexpressing cells surrounding the lateral ventricle compared with wild-type littermates at any of the ages examined (supplemental Fig. S3, available at www.jneurosci.org as supplemental material). The fact that GFAP and BLBP are both expressed in adult astrocytes (in addition, BLBP is also expressed in a population of postmitotic neurons) led us to question whether the apparently 


\section{BrdU for 14 days chase for 12 days P18 P30} P4
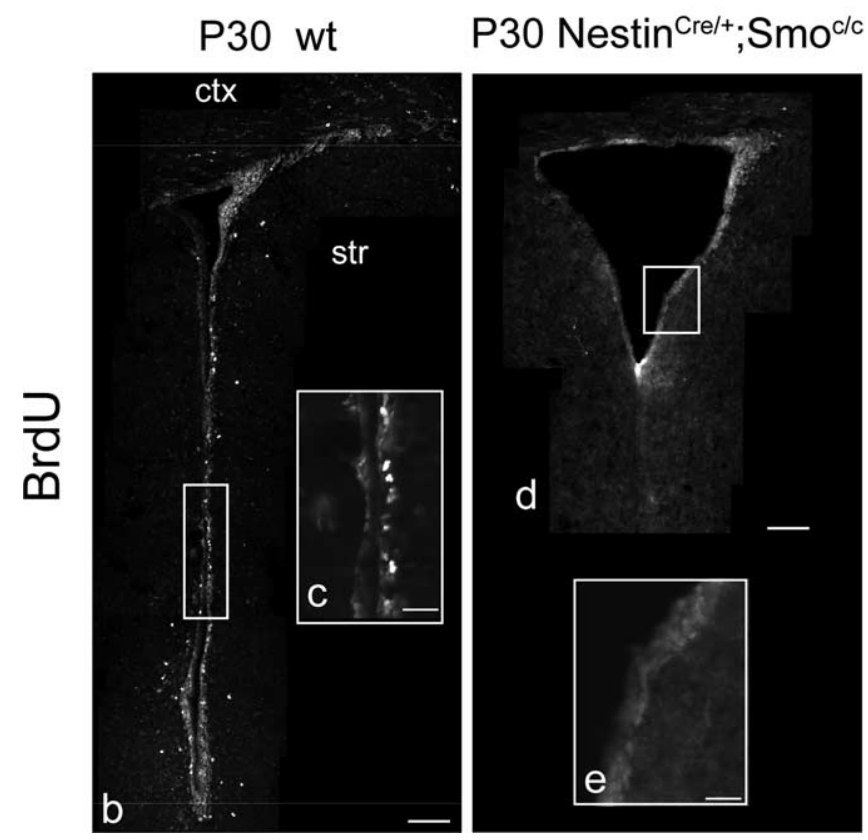

Figure 3. By P30, slow-dividing B cells are absent in conditional Smoothened-null mice. $\boldsymbol{a}$, The diagram shows the protocol used for marking quiescent $B$ cells at P30. $\boldsymbol{b}-\boldsymbol{e}$, BrdUincorporating cells in the SVZ of wild-type $(\boldsymbol{b}, \boldsymbol{c})$ and Nestin ${ }^{\mathrm{Cre} /+} ; \mathrm{Smo}^{c / c}(\boldsymbol{d}, \boldsymbol{e})$ animals at P3O. $\boldsymbol{b}$, $\boldsymbol{d}$, Coronal views of the whole SVZ.c,e, Enlargements from the appropriate areas shown in $\boldsymbol{b}$ and $\boldsymbol{d}$, respectively. ctx, Cortex; str, striatum. Scale bars: $\boldsymbol{b}, \boldsymbol{d}, 100 \mu \mathrm{m} ; \boldsymbol{c}, \boldsymbol{e}, 20 \mu \mathrm{m}$.

unperturbed expression of these markers was indicative of the $\mathrm{B}$ cell population being normal in these mutants. To directly assess the status of slow-dividing stem cells in the SVZ of P30 Nestin ${ }^{\mathrm{Cre} /+} ; \mathrm{Smo}^{c / c}$ mutants, we performed a pulse-chase BrdU experiment. We administered BrdU to the drinking water of wild-type and $\mathrm{Nestin}^{\mathrm{Cre} /{ }^{+}} ; \mathrm{Smo}^{c / c}$ mutant mice for two consecutive weeks (from P4 to P18), followed by a $12 \mathrm{~d}$ chase period. This procedure allowed for the specific labeling of the slow-dividing stem cell population, as most fast-cycling cells dilute out the BrdU during the chase period (Fig. $3 a$, diagram). After such treatment, the cells retaining BrdU [LRCs (long-retaining cells)] should essentially identify the slow-dividing B cells, because they do not undergo cell divisions during the chase period (Morshead et al., 1994; Chiasson et al., 1999; Doetsch et al., 1999a; Capela and Temple, 2002). In the control animals, we found many BrdU + cells surrounding the ventricle, whereas almost no BrdU + cells were detected in the mutants (Fig. $3 b-e$ ). As expected, in wild-type animals these BrdU+ cells colabeled with GFAP. Even assuming that a $12 \mathrm{~d}$ chase period is insufficient time to dilute out all BrdU from the $\mathrm{C}$ cell population, the almost complete absence of BrdU labeling in mutant animals suggests that in $\mathrm{P} 30 \mathrm{Nestin}^{\mathrm{Cre} /+} ; \mathrm{Smo}^{c / c}$ mutants, the B stem cell population is almost completely depleted. Notably, this is possibly attributable to reduced survival of $\mathrm{B}$ cells in this mutant.

\section{Ependymal cells are unaffected by the loss of}

\section{Hedgehog signaling}

Lining the lateral ventricles are the highly differentiated postmitotic ependymal cells (E cells) that separate the SVZ from the cerebrospinal liquid (Chiasson et al., 1999; Doetsch et al., 1999a; Spassky et al., 2005). Because E cells, as well as B, C, and A cells, also express Nestin (Doetsch et al., 1997), recombination of the conditional Smoothened allele likely occurs in the E cells, suggesting that this population loses Hh signaling in the mutant animals that we studied. To test whether this cell population is affected by the removal of Hh signaling, we performed immunocytochemical staining with S100- $\beta$ (supplemental Fig. S4a,b, available at www.jneurosci.org as supplemental material), a calcium-binding protein specifically expressed in E cells (Craig et al., 1996) and mCD24 (supplemental Fig. S4c, $d$, available at www.jneurosci.org as supplemental material), a glycosylphosphatidylinositolanchored membrane glycoprotein expressed in E and A cells (Calaora et al., 1996; Spassky et al., 2005). We did not detect a difference between wild-type and mutant animals, suggesting that this population is unaffected by the loss of $\mathrm{Hh}$ signaling.

\section{C cells are decreased from P8 onward}

To assess the effects of loss of Hh signaling on the SVZ transitamplifying population, we analyzed the expression of Mash1 in the SVZ of wild-type mice and $\mathrm{Nestin}^{\mathrm{Cre} /+} ; \mathrm{Smo}^{c / c}$ mutants at a series of ages between P0 and P30. Recent work (Parras et al., 2004) revealed that the SVZ transit-amplifying cells (C cells) express the bHLH transcription factor Mash1. Consistent with these findings, when we performed a $1 \mathrm{~h}$ BrdU pulse-kill experiment on P30 wt animals, we found that a large population of Mash1-expressing cells was also BrdU positive (Fig. $4 b, c$ ). At P0, we found the staining of wild-type and $\mathrm{Nestin}^{\mathrm{Cre} /+} ; \mathrm{Smo}^{c / c}$ mutant SVZ to be indistinguishable (data not shown). In contrast, we found that the expression of Mash1 is strongly reduced in Nestin ${ }^{\mathrm{Cre} /+} ; \mathrm{Smo}^{c / c}$ mutants at P8 (Fig. 4e-h), P15 (data not shown), and P30 (supplemental Fig. S5, available at www. jneurosci.org as supplemental material), demonstrating that the postnatal SVZ transit-amplifying cells are drastically affected by the loss of Hh signaling. Quantitative analysis of the decline in the Mash1-expressing C cell population closely paralleled the reduction in proliferation within the SVZ over the same time course (compare Figs. 1q, 4d). Specifically, the reduction in the Mash1expressing $\mathrm{C}$ population in mutant versus wild-type animals was to $40 \%$ at $\mathrm{P} 8,30 \%$ at $\mathrm{P} 15$, and $28 \%$ at $\mathrm{P} 30$. Surprisingly, despite reductions in the number of Mash1-expressing $\mathrm{C}$ cells, we did not detect colabeling of Mash 1 and caspase- 3 in P8 and P15 mutants, suggesting that the decline in $\mathrm{C}$ cell number is not the result of apoptosis within this population (Fig. 4i).

\section{A cells are expanded at P8 but decreased at P30}

A marker specific for migrating neuroblasts (A cells) is the microtubule-associated protein Dcx (Francis et al., 1999; Gleeson et al., 1999; Englund et al., 2002; Brown et al., 2003; Yang et al., 2004). To evaluate how the A cell population is affected by the loss of Hh signaling during the postnatal period, we examined this marker at the same set of time points used above. Although the expression of Dcx was normal at P0, the number of SVZ cells expressing Dcx was grossly expanded at P8 and to a lesser extent at P15. In contrast, by P30 the number of Dcx-expressing cells had declined such that there were in fact fewer Dcx-expressing cells observed in $\mathrm{Nestin}^{\mathrm{Cre} /+} ; \mathrm{Smo}^{c / c}$ mutants than in wild-type controls (Fig. $5 a-f$ ). In sagittal sections, the migratory path of newborn neurons is quite evident as they transit from the SVZ to the $\mathrm{OB}$ and is referred to as the rostral migratory stream (RMS) (Lois et al., 1996). At P8, when the expansion of A cells is at its zenith, the RMS looked quite abnormal in mutant animals: A cells appeared to pile up at the striatocortical angle, and only few 

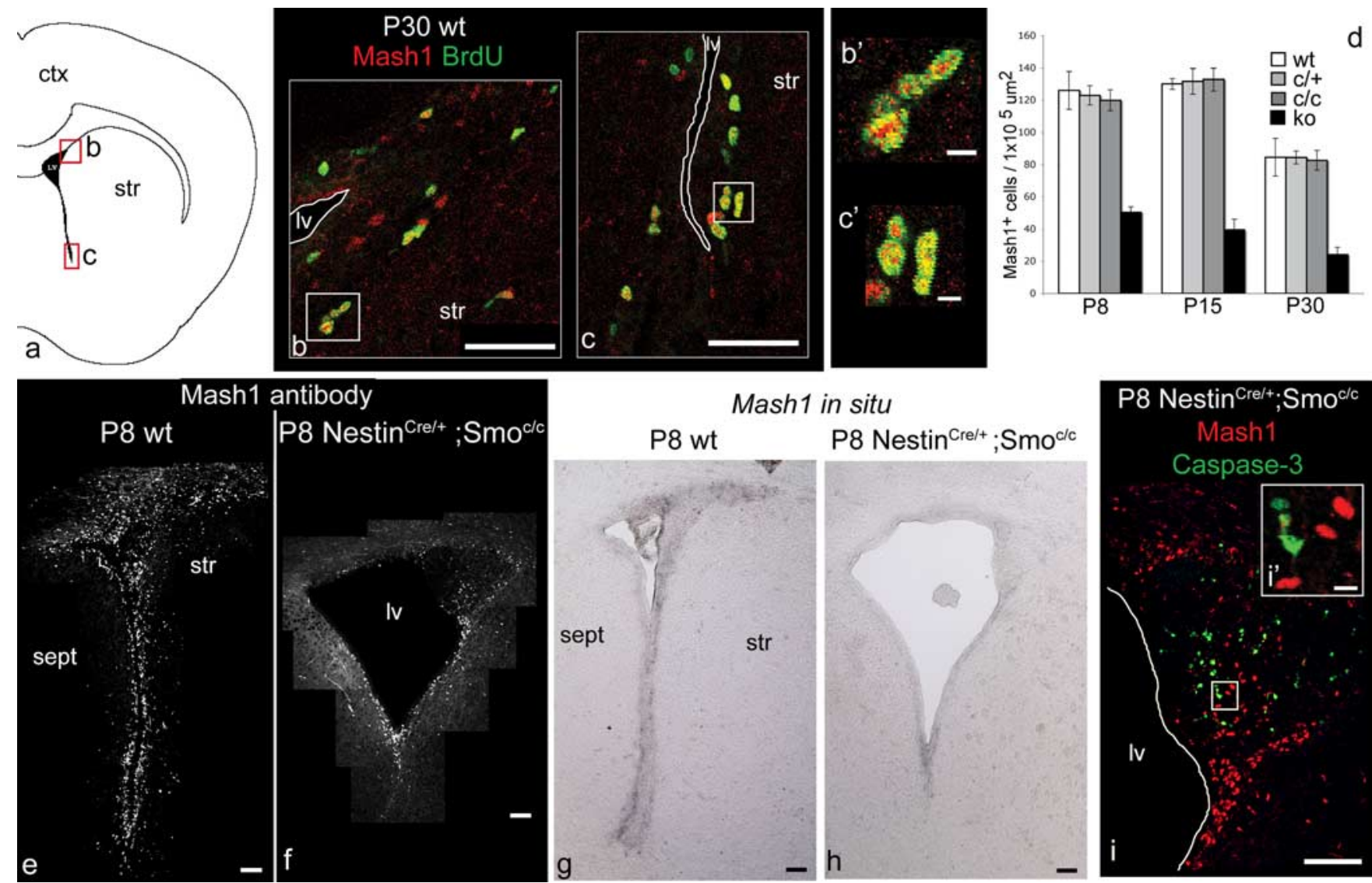

in situ
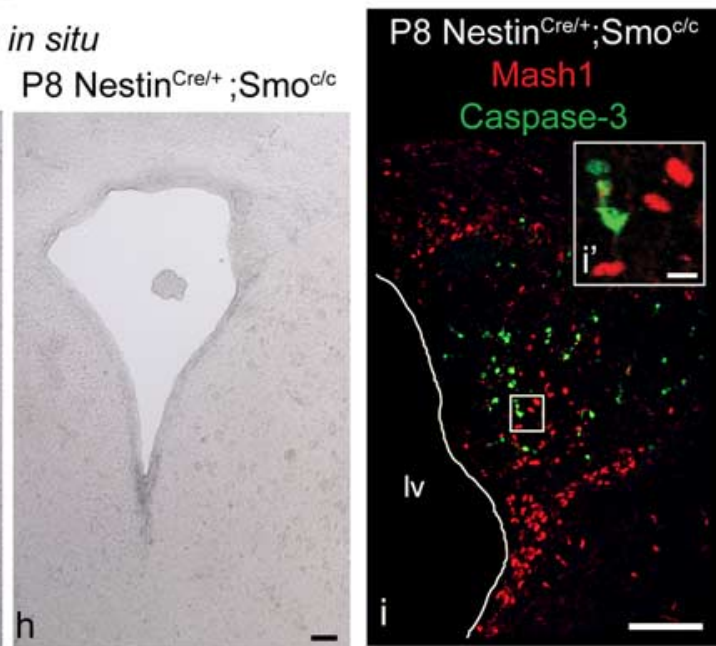

Figure 4. C cells are decreased by P8 onward in conditional Smoothened-null mice, but this reduction is not the result of apoptosis within C cells. $\boldsymbol{a}$, Schematic of the lateral ventricle and SVZ, showing the two areas corresponding to $\boldsymbol{b}$ and $\boldsymbol{c} . \boldsymbol{b}, \boldsymbol{c}$, Double labeling for BrdU (in green) and Mash1 (in red) in P30 wild-type mice after one intraperitoneal injection of BrdU $1 \mathrm{~h}$ before the mice were killed. $\boldsymbol{b}^{\prime}, \boldsymbol{c}^{\prime}$, Enlargements from the appropriate areas shown in $\boldsymbol{b}$ and $\boldsymbol{c}$, respectively. $\boldsymbol{d}$, Data in $\boldsymbol{e}$ and $\boldsymbol{f}$, together with other ages (P15 and P30) and additional controls (Smo $0^{c /+}$ and Smo $\left.0^{c / /}\right)($ shown in supplemental Fig. 55, available at www.jneurosci.org as supplemental material) are quantitated. $\boldsymbol{e}-\boldsymbol{h}$, Coronal views of the whole SVZ showing Mash1 immunocytochemical staining (e, $\boldsymbol{f}$ ) and in situ hybridization for Mash1 expression $(\boldsymbol{g}, \boldsymbol{h})$ in wild-type $(\boldsymbol{e}, \boldsymbol{g})$ and Nestin ${ }^{\mathrm{Cr} /+} ;{ }_{;} \mathrm{Smo}^{\mathrm{cc}}(\boldsymbol{f}, \boldsymbol{h})$ animals at P8. $\boldsymbol{i}$, Coronal view of the striatocortical angle of the SVZ showing double labeling for caspase-3 (in green) and Mash1 (in red) in P8 Nestin ${ }^{\text {Cre/ }}{ }_{;}$STmo mice; there is no colabeling between those markers. $i^{\prime}$, Enlargement from the appropriate area shown in $i$. ctx, Cortex; str, striatum; sept, septum; Iv, lateral ventricle; ko, knock-out. Scale bars: $\boldsymbol{b}, \boldsymbol{c}, 50 \mu \mathrm{m} ; \boldsymbol{b}^{\prime}, \boldsymbol{c}^{\prime}, 5 \mu \mathrm{m} ; \mathbf{e}-\boldsymbol{i}, 100 \mu \mathrm{m} ; \boldsymbol{i}^{\prime}, 10 \mu \mathrm{m}$. Error bars represent SD. Statistics were performed by ANOVA; at all ages, $p$ is $<0.0001$.

of them seemed able to migrate to the OB. At P30, when the A cell population has declined below that seen in wild-type mice, the RMS was grossly abnormal, as evidenced by it becoming extremely thin (Fig. $5 g-l$ ). Consistent with these observations, we detected a similar pattern of changes in the expression of $D l \times 2$, a homeodomain transcription factor expressed by both $\mathrm{C}$ and $\mathrm{A}$ cells (Doetsch et al., 1999a). In situ analysis shows that mRNA levels of Dlx2 in mutant animals were increased at P8 in the striatocortical angle, slightly decreased at P15, and strongly reduced at P30 (Fig. 6a-f). In addition, Dlx expression (as assessed by a pan-Dlx antibody) in $\mathrm{Nestin}^{\mathrm{Cre} /+} ; \mathrm{Smo}^{c / c}$ mutants followed these same changes (Fig. $6 g-l$ ). Given our analysis showing that Mash1-expressing cells are drastically reduced in number from P8 onward (Fig. 4), the increased expression of $D l \times 2$ must reflect the expanded A cell population (Fig. 5).

Given that the observed cell death did not appear to be within the $\mathrm{C}$ cell population, combined with localization of the apoptotic cells to the striatocortical angle, where the majority of the A cell population resides, we asked whether A cells were undergoing apoptosis. As expected, we detected colabeling of Dcx and caspase- 3 in P8 and P15 mutant SVZ (Fig. 7), confirming that it is indeed the A cell population that is undergoing cell death.
Migratory ability in vitro is unperturbed in $\mathrm{Nestin}^{\mathrm{Cre} /+} ; \mathrm{Smo}^{c / c}$ mutant A cells

There are two possible explanations for why mutant A cells might accumulate within the striatocortical angle and undergo apoptosis. First, A cell migration may be cell-autonomously impaired. Alternatively, the massive overproduction of A cells may result in too many A cells in the striatocortical angle competing for a limited supply of trophic factors. To investigate whether A cells are intrinsically impaired in their migratory ability, we cultured SVZ explants from P8 mutant and control animals in Matrigel, a technique previously developed by Wichterle et al. (1997). In these conditions, it has been shown that after $3 \mathrm{~d}$ in culture, A cells are able to form the characteristic chains typical of their normal migratory behavior within the RMS. To verify that these cells corresponded to the migrating neuronal precursors observed in vivo, we analyzed Dcx immunoreactivity and found that the wt chains were Dcx + (Fig. 8). We also stained for GFAP immunoreactivity and found that the migrating cells were GFAP negative (Fig. 8), demonstrating that these cells were migrating without the aid of radial glia or B cells (Wichterle et al., 1997). Using this assay, we did not see any obvious difference between the ability of A cells from mutant and control explants to undergo chain migration (Fig. 8). 


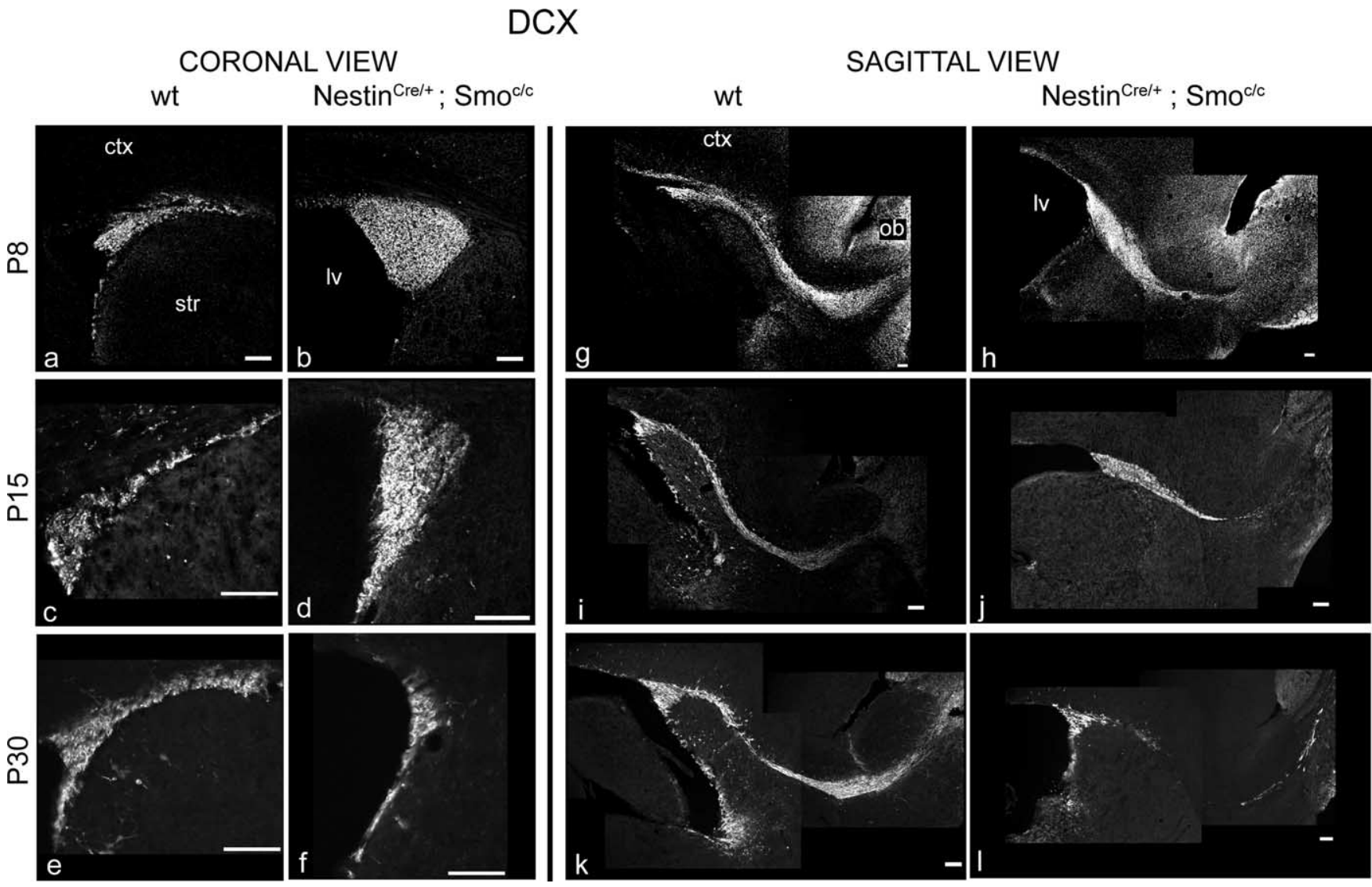

Figure 5. A cells are expanded at P8 but decreased at P30 in conditional Smoothened-null mice. $\boldsymbol{a}-\boldsymbol{l}$, Doublecortin immunocytochemical staining in the SVZ of wild-type $(\boldsymbol{a}, \boldsymbol{c}, \boldsymbol{e}, \boldsymbol{g}, \boldsymbol{i}, \boldsymbol{k})$ and $\mathrm{Nestin}^{\mathrm{Cre} /+} ; \mathrm{SmO}^{\mathrm{clc}}(\boldsymbol{b}, \boldsymbol{d}, \boldsymbol{f}, \boldsymbol{h}, \boldsymbol{j}, \boldsymbol{l})$ animals at P8 $(\boldsymbol{a}, \boldsymbol{b}, \boldsymbol{g}, \boldsymbol{h}), \mathrm{P} 15(\boldsymbol{c}, \boldsymbol{d}, \boldsymbol{i}, \boldsymbol{j})$, and P30 $(\boldsymbol{e}, \boldsymbol{f}, \boldsymbol{k}, \boldsymbol{l}), \boldsymbol{a}-\boldsymbol{f}$, Coronal views of the striatocortical angle of the SVZ. $\boldsymbol{g}-\boldsymbol{l}$, Sagittal views of the SVZ and RMS. ctx, Cortex; str, striatum; Iv, lateral ventricle. Scale bars, $100 \mu \mathrm{m}$.

These results suggest that A cells lacking Hh signaling have the same ability to migrate as wild-type cells when placed in a permissive in vitro environment. This is consistent with the possibility that a lack of trophic support may underlie the observed cell death within the A cell population.

The migration defect of neuroblasts lacking Hh signaling can be non-cell-autonomously rescued in vivo

To analyze in vivo the A cell migration defect, we performed a series of homotopic and homochronic transplants (Fig. 9a). We dissected and dissociated SVZ cells from perinatal (P8) mutant mice carrying the $\beta$-actin ${ }^{E G F P /+}$ allele (Okabe et al., 1997) $\left(\mathrm{Nestin}^{\mathrm{Crel+}} ; \mathrm{Smo}^{c / c} ; \beta\right.$-actin ${ }^{\text {EGFP/+ }}$ animals) and transplanted these mutant GFP-labeled cells in the SVZ of Nestin ${ }^{\mathrm{Cre} /+} ; \mathrm{Smo}^{c / c}$ animals $(n=6)$. When we analyzed the transplanted mice 1 week later (at P15), we found almost no GFP+ mutant cells migrating through the RMS and correspondingly very few labeled cells within the $\mathrm{OB}$ of mutant hosts (Fig. $9 b-d$ ).

To address whether Hh signaling is required cell autonomously or nonautonomously for migration, we homotopically injected $\mathrm{Nestin}^{\mathrm{Cre} /+} ; \mathrm{Smo}^{c / c} ; \beta$-actin ${ }^{E G F P /+}$ SVZ cells into wt animals $(n=6)$. We observed many GFP + mutant cells migrating through the RMS and reaching the granular layer of the $\mathrm{OB}$ of wt hosts (Fig. $9 b, e, f$ ). This suggests that the failure in migration observed in A cells lacking Hh signaling can be rescued noncell-autonomously. We also observed that SVZ cells from $\beta$-actin ${ }^{E G F P /+}$ animals can migrate normally, when injected in the SVZ of Nestin ${ }^{\mathrm{Crel}+} ; \mathrm{Smo}^{c / c}$ animals $(n=10)$ (Fig. 9b,g,h). This suggests that wt cells using an autocrine mechanism were able to provide themselves the factor required for their normal migration in mutant hosts. Indeed, when SVZ cells from $\beta$-actin ${ }^{E G F P /+}$ animals were injected homotopically into wt animals $(n=5)$, migration was comparable with that observed in wt SVZ in mutant hosts or vice versa (Fig. 9b,i,j). Together these data suggest that the reception of Hedgehog signaling in SVZ neuroblasts results in the production of a nonautonomous signal required for the migration of SVZ cells. Moreover, our results demonstrate that this signal can act in both an autocrine (as demonstrated by the normal migration of wt A cells in mutant animals) and paracrine (as demonstrated by the rescue of mutant A cell migration when placed in wt animals) manner.

Recent work (Nguyen-Ba-Charvet et al., 2004) showed that Slit1 is expressed in A and C cells of adult mice and is involved in the regulation of the migration of $\mathrm{OB}$ precursors. To examine whether Slit1 is the nonautonomous signal required for the proper migration of SVZ cells, we performed in situ analysis to evaluate the mRNA levels of Slit1 in the RMS of Nestin ${ }^{\mathrm{Cre} /+}$; $S m o^{c / c}$ mutants. We observed a marked decrease in Slit1 mRNA levels at P8 compared with wt animals (Fig. 10), suggesting that the production of this secreted factor may be Hh dependent. Hence, this may provide an explanation for the failed migration of mutant A cells in $\mathrm{Nestin}^{\mathrm{Cre} /+} ; \mathrm{Smo}^{c / c}$ animals.

\section{Discussion}

The present study shows the effects of the embryonic removal of Smo in the SVZ stem cell lineage at different time points. Based on 


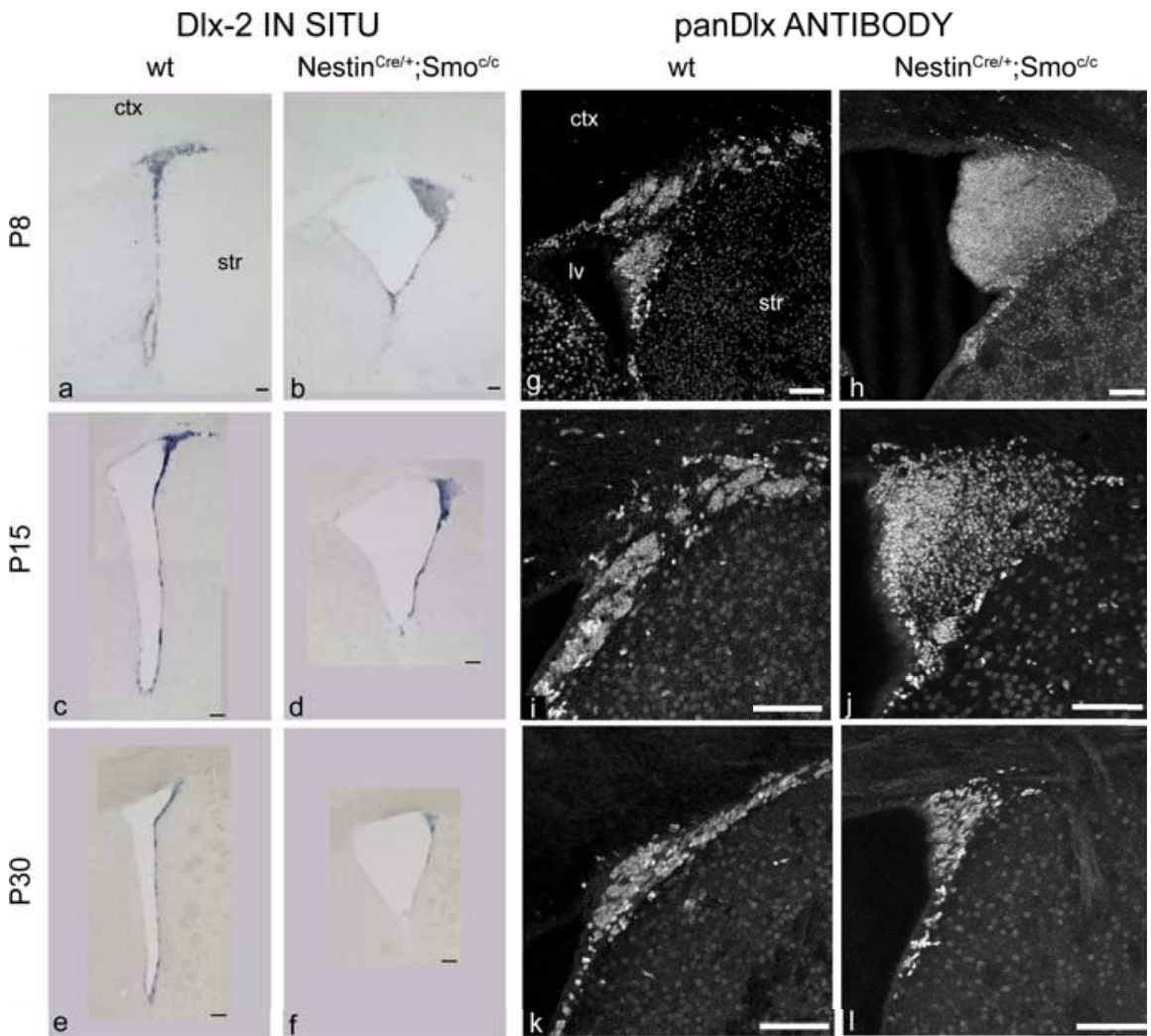

Figure 6. The pool of $\mathrm{Dlx}+$ cells is expanded at $\mathrm{P} 8$ but reduced by $\mathrm{P} 30$ in conditional Smoothened-null mice. $\boldsymbol{a}-\boldsymbol{f}$, Coronal views of the whole SVZ showing in situ hybridization for Dlx-2 expression in wild-type $(\boldsymbol{a}, \boldsymbol{c}, \boldsymbol{e})$ and Nestin ${ }^{\mathrm{Cre} /+} ; \mathrm{Smo}^{c / c}(\boldsymbol{b}, \boldsymbol{d}, \boldsymbol{f})$ animals at P8 $(\boldsymbol{a}, \boldsymbol{b}), \mathrm{P} 15(\boldsymbol{c}, \boldsymbol{d})$, and P30 (e, $\boldsymbol{f}) . \boldsymbol{g}-\mathbf{I}$, Coronal views of the striatocortical angle of the SVZ showing pan-Dlx immunocytochemical staining in wild-type $(\boldsymbol{g}, \boldsymbol{i}, \boldsymbol{k})$ and Nestin ${ }^{\mathrm{Cre} /+} ; \mathrm{Smo}^{c / c}(\boldsymbol{h}, \boldsymbol{j}, \boldsymbol{I})$ animals at P8 $(\boldsymbol{g}, \boldsymbol{h}), \mathrm{P} 15(\boldsymbol{i}, \boldsymbol{j})$, and P30 $(\boldsymbol{k}, \boldsymbol{I})$. ctx, Cortex; str, striatum; lv, lateral ventricle. Scale bars, $100 \mu \mathrm{m}$.

\section{Caspase-3 DCX}

Nestin ${ }^{\mathrm{Cre} /+} ; \mathrm{Smo}^{\mathrm{clc}}$
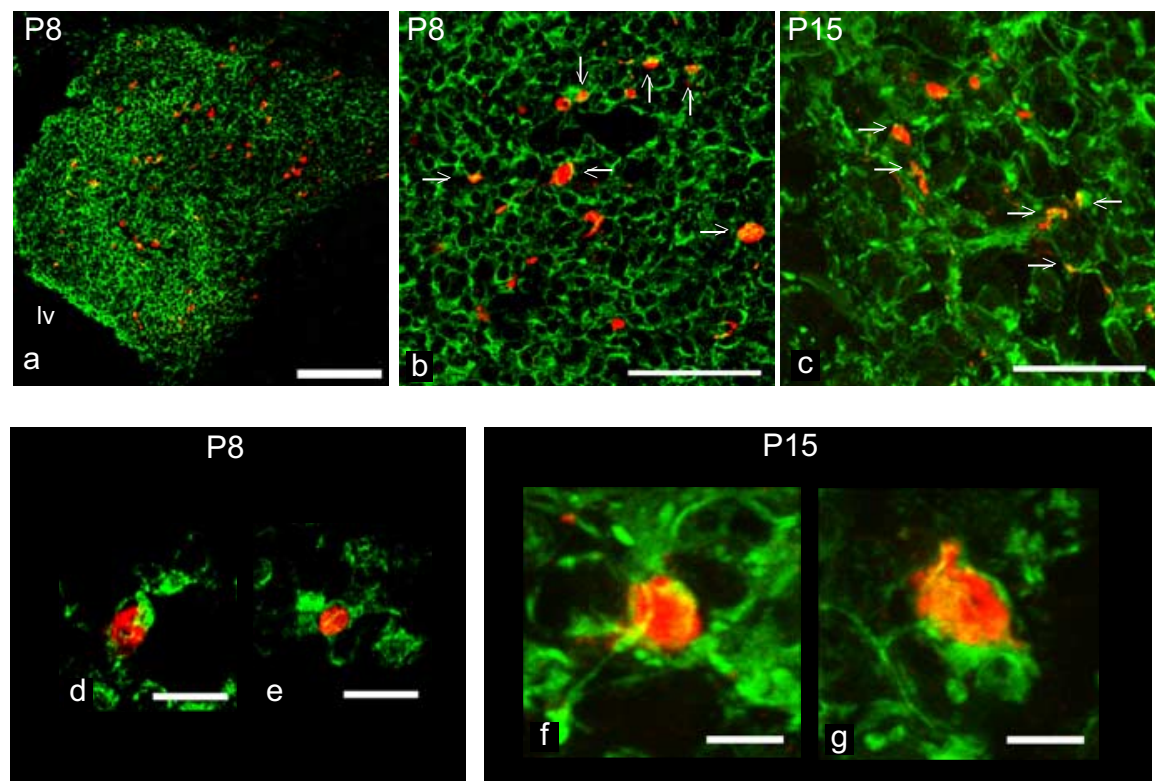

Figure 7. A cells undergo apoptosis in conditional Smoothened-null mice. $\boldsymbol{a}-\boldsymbol{g}$, Coronal views of the striatocortical angle of the SVZ in Nestin ${ }^{\mathrm{Cre} /+} ;$; Smoc/c animals at P8 $(\boldsymbol{a}, \boldsymbol{b}, \boldsymbol{d}, \boldsymbol{e})$ and P15 $(\boldsymbol{c}, \boldsymbol{f}, \boldsymbol{g})$ immunostained for DCX (in green) and caspase-3 (in red): arrows indicate colabeling between those markers. $\boldsymbol{d}-\boldsymbol{f}$, High-magnification shots of individual cells that show colabeling. Iv, Lateral ventricle. Scale bars: $\boldsymbol{a}, 100 \mu \mathrm{m} ; \boldsymbol{b}, \boldsymbol{c}, 50 \mu \mathrm{m} ; \boldsymbol{d}, \boldsymbol{e}, 10 \mu \mathrm{m} ; \boldsymbol{f}, \boldsymbol{g}, 5 \mu \mathrm{m}$. the findings that subsets of quiescent adult neural stem cells (B cells) and transitamplifying cells ( $\mathrm{C}$ cells) are Hh responsive (Ahn and Joyner, 2005; Palma et al., 2005), we expected that $B$ and $C$ cells and not A cells would be affected in conditional Smo mice. We demonstrate that although normal at birth, the $\mathrm{B}$ and $\mathrm{C}$ cell populations within the SVZ become rapidly depleted during the first two postnatal weeks (Figs. 3, 4). In contrast, and likely as a result of the precocious maturation of neurons from the niche, A cells are grossly overproduced during the first postnatal week but are subsequently reduced in number (Fig. 5). These results suggest that Hedgehog signaling may function in at least two distinct ways to promote postnatal neurogenesis. First, as has been suggested previously (Lai et al., 2003; Machold et al., 2003; Palma et al., 2005), Hedgehog may function as a mitogen to promote the active proliferation of transit-amplifying $C$ cells (Figs. 1, 4). Second, it may act as a critical factor for the maintenance of the self-renewing, slowly dividing $B$ cell population. Hence, Hh signaling surprisingly can either preserve stem cells in a quiescent state or alternatively promote their active division at the next step of their lineage. Whether these observations are a direct reflection of the actions of Hh signaling on proliferation or reveal a requirement of $\mathrm{Hh}$ for the progressive maintenance of niche progenitors in a $\mathrm{B}$ or $\mathrm{C}$ cell state is at present unclear.

The effect of the loss of Hh signaling on A cells is equally intriguing. Although increased in number (Fig. 5) and capable of undergoing robust migration as assessed in vitro (Fig. 8), these cells fail to migrate normally to the olfactory bulbs in vivo as assessed by homotopic-homochronic transplants (Fig. 9). Instead, they accumulate in the striatocortical angle, and a large portion of these supernumerary A cells undergoes apoptosis (Fig. 7). It is possible that because of the high concentration of A cells in the striatocortical angle, trophic factors become limiting. One attractive possibility is that the $\mathrm{B}$ or $\mathrm{C}$ cells themselves provide trophic support for A cells, and the depletion of these progenitor populations directly results in the death of young neuroblasts. Alternatively, the overabundance of A cells within the RMS may create a bottleneck, which as a result of sheer density triggers apoptosis.

Notably, despite their perinatal overproduction, only a small number of A cells is able to reach the olfactory bulbs. Why the A cell population, which based on its in vitro behavior is clearly capable of robust 


\section{GFAP}

wt
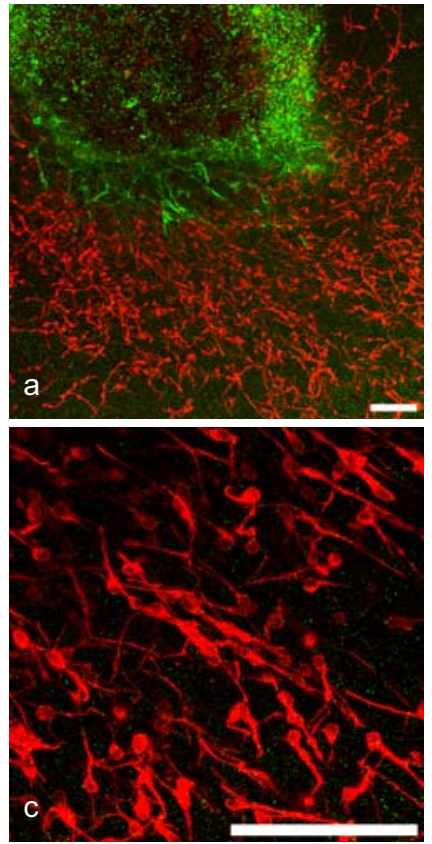
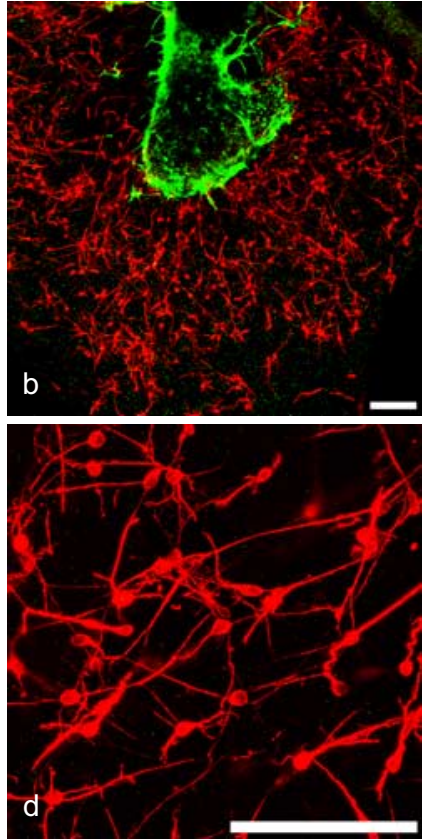

Nestin ${ }^{\mathrm{Cre} /+} ; \mathrm{Smo} / \mathrm{c}$

Figure 8. A cells lacking Hh signaling migrate normally in vitro. $\boldsymbol{a}-\boldsymbol{d}$, Double labeling for $D C X$ (in red) and GFAP (in green) of SVZ explants grown in Matrigel coming from wild-type $(\boldsymbol{a}, \boldsymbol{c})$ and Nestin ${ }^{\mathrm{Cre} /+} ;$ Smo $\mathrm{O}^{c / \boldsymbol{c}}(\boldsymbol{b}, \boldsymbol{d})$ animals at P8. $\boldsymbol{c}, \boldsymbol{d}$, Enlargements of $\boldsymbol{a}$ and $\boldsymbol{b}$, respectively. Scale bars, $100 \mu \mathrm{m}$.

migration, fails to do so in $\mathrm{Nestin}^{\mathrm{Cre} /+} ; \mathrm{Smo}^{c / c}$ mutants is an interesting puzzle. To address this question, we undertook a set of experiments in which mutant SVZ cells were homotopically/homochronically transplanted into wt hosts and vice versa. We observed that mutant SVZ cells are able to migrate in wt hosts, and conversely wt SVZ cells are able to migrate in mutant hosts. The most parsimonious explanation for these findings is that a nonautonomous Hh-dependent signal required for migration is produced by A cells. Our observations are reminiscent of the finding that A cells both secrete and receive Slit ligand and that this signaling is required for their migration (Nguyen-Ba-Charvet et al., 2004). Indeed, we observe that the expression of Slit1 is strongly reduced in the SVZ and RMS of $\mathrm{Nestin}^{\mathrm{Cre} /+} ; \mathrm{Smo}^{c / c}$ animals (Fig. 10). Hence, the expression of Slit1 in A cells is Hh dependent. This suggests that the reduction of Slit1 expression may be the cause of the observed defect in the migration of A cells in mutant animals.

In light of previous reports of connections between cilia and both $\mathrm{Hh}$ and Slit signaling, our results are particularly intriguing. Recent studies have shown that the choroid plexus cells secrete Slit protein in vitro (Nguyen-Ba-Charvet et al., 2004) and in vivo (Sawamoto et al., 2006). Moreover, it has also been shown that the beating of ependymal cilia is required for the directional migration of young neuroblasts (Sawamoto et al., 2006). With regard to Hh signaling, previous studies (Corbit et al., 2005; Haycraft et al., 2005; Huangfu and Anderson, 2005; Liu et al., 2005; May et al., 2005) have found that numerous proteins associated with cilia function (intraflagellar transport proteins) play a role in transduction of Hh signaling, although the functional importance of cilia in Hh signaling it is not yet clear. Our results potentially reveal an unanticipated connection between $\mathrm{Hh}$ and Slit signaling that may occur within the ependymal cilia. However, in

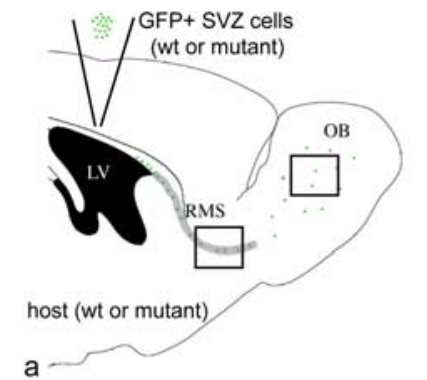

RMS
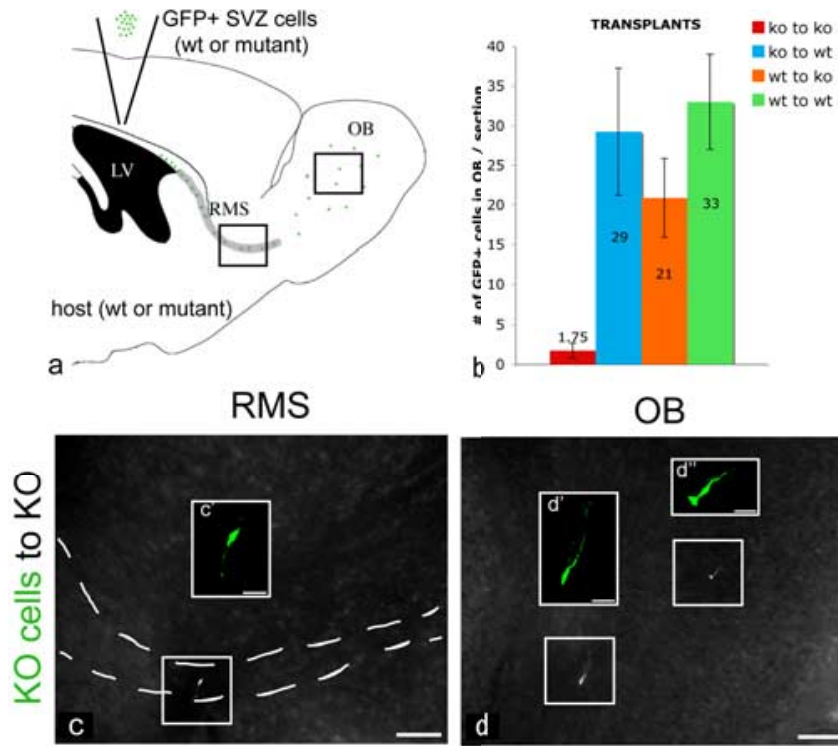

$\mathrm{OB}$
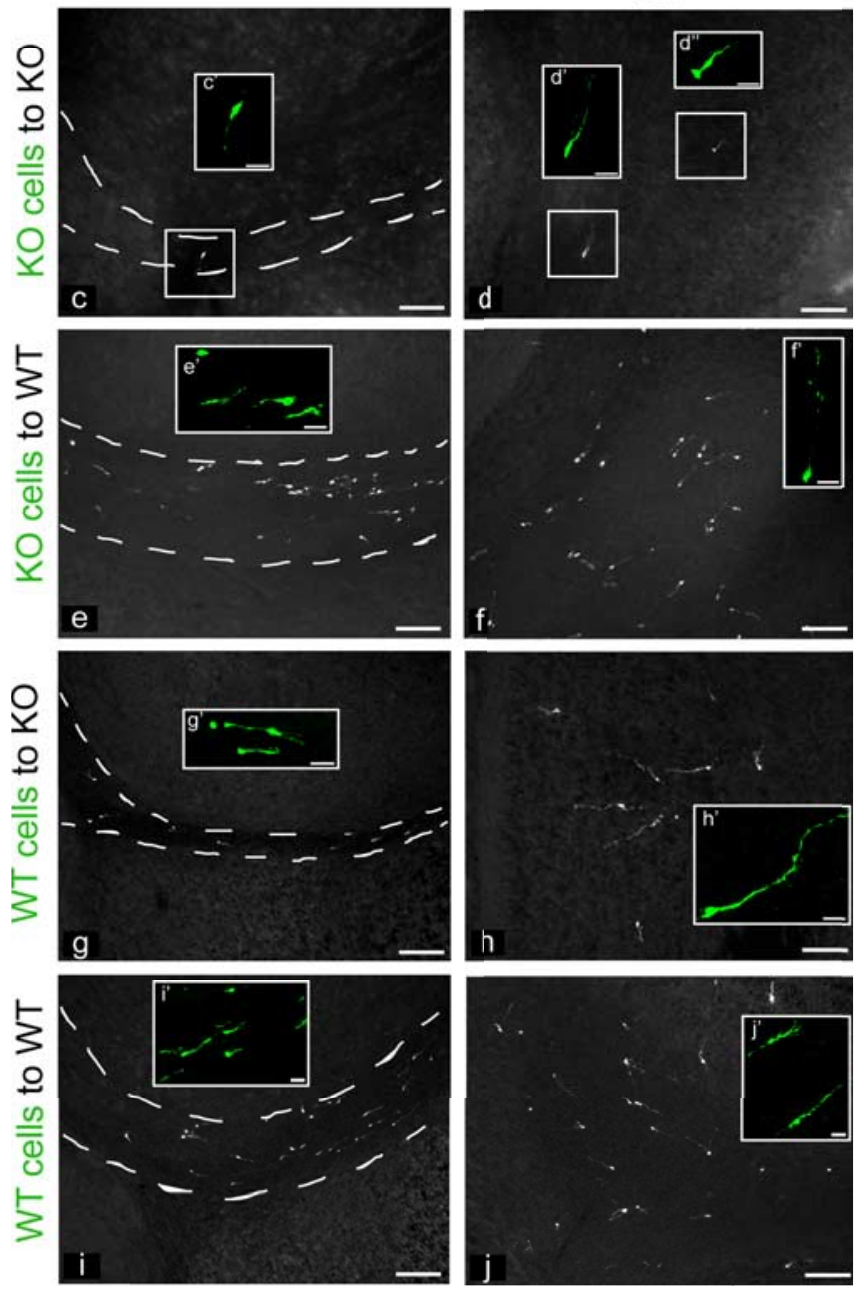

Figure 9. Hedgehog signaling is nonautonomously required for the migration of A cells. $\boldsymbol{a}$, The diagram shows the protocol used for transplants: we dissected and dissociated SVZ cells from either perinatal (P8) mutant or wt mice, carrying the $\beta$-actin ${ }^{E G F /+}$ allele, and reciprocally transplanted these GFP-labeled cells into the SVZ of mutant or wt animals. We analyzed mice that received transplants 1 week later, at P15. $\boldsymbol{b}$, Quantitation of the four types of transplants performed: SVZ cells from Nestin ${ }^{\mathrm{Cre} /+} ; \mathrm{Smo}^{\mathrm{cc} ;} ; \beta$-actin ${ }^{\mathrm{EGFP} /+}$ animals were homotopically in-

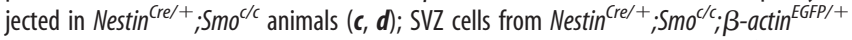
animals were injected into the SVZ of wt animals $(\boldsymbol{e}, \boldsymbol{f})$; SVZ cells from $\beta$-actin ${ }^{E G P P /+}$ animals were homotopically injected in Nestin ${ }^{\mathrm{Cre} /+} ; \operatorname{Smo}^{c / c}$ animals $(\boldsymbol{g}, \boldsymbol{h})$; and SVZ cells from $\beta$-actin ${ }^{E G P /+}$ animals were injected into the SVZ of wt animals $(\boldsymbol{i}, \boldsymbol{j}) . \mathbf{c}-\boldsymbol{j}$, Sagittal views of the RMS $(\boldsymbol{c}, \boldsymbol{e}, \boldsymbol{g}, \boldsymbol{i})$ and $\mathrm{OB}(\boldsymbol{d}, \boldsymbol{f}, \boldsymbol{h}, \boldsymbol{j})$ of P15 transplanted mice showing immunocytochemical staining for GFP. $\boldsymbol{c}^{\prime}, \boldsymbol{d}^{\prime}, \boldsymbol{d}^{\prime \prime}, \boldsymbol{e}^{\prime}, \boldsymbol{f}^{\prime}, \boldsymbol{g}^{\prime}, \boldsymbol{h}^{\prime}, \boldsymbol{i}^{\prime}, \boldsymbol{j}^{\prime}$, Examples of migrating neuroblasts in the RMS $\left(\boldsymbol{c}^{\prime}, \boldsymbol{e}^{\prime}, \boldsymbol{g}^{\prime}, \boldsymbol{i}^{\prime}\right)$ and interneurons in the granule layer of the OB $\left(\boldsymbol{d}^{\prime}, \boldsymbol{d}^{\prime \prime}, \boldsymbol{f}^{\prime}, \boldsymbol{h}^{\prime}, \boldsymbol{j}^{\prime}\right)$. LV, Lateral ventricle; ko, knock-out. Scale bars: $\boldsymbol{c}-\boldsymbol{j}, 100 \mu \mathrm{m} ; \boldsymbol{c}^{\prime}, \boldsymbol{d}^{\prime}, \boldsymbol{d}^{\prime \prime}, \boldsymbol{e}^{\prime}, \boldsymbol{f}^{\prime}, \boldsymbol{g}^{\prime}, \boldsymbol{h}^{\prime}, \boldsymbol{i}^{\prime}, \boldsymbol{j}^{\prime}, 20 \mu \mathrm{m}$. Error bars represent SD. Statistics were performed by ANOVA; $p=0.011$. 


\section{Slit1 in situ P8}

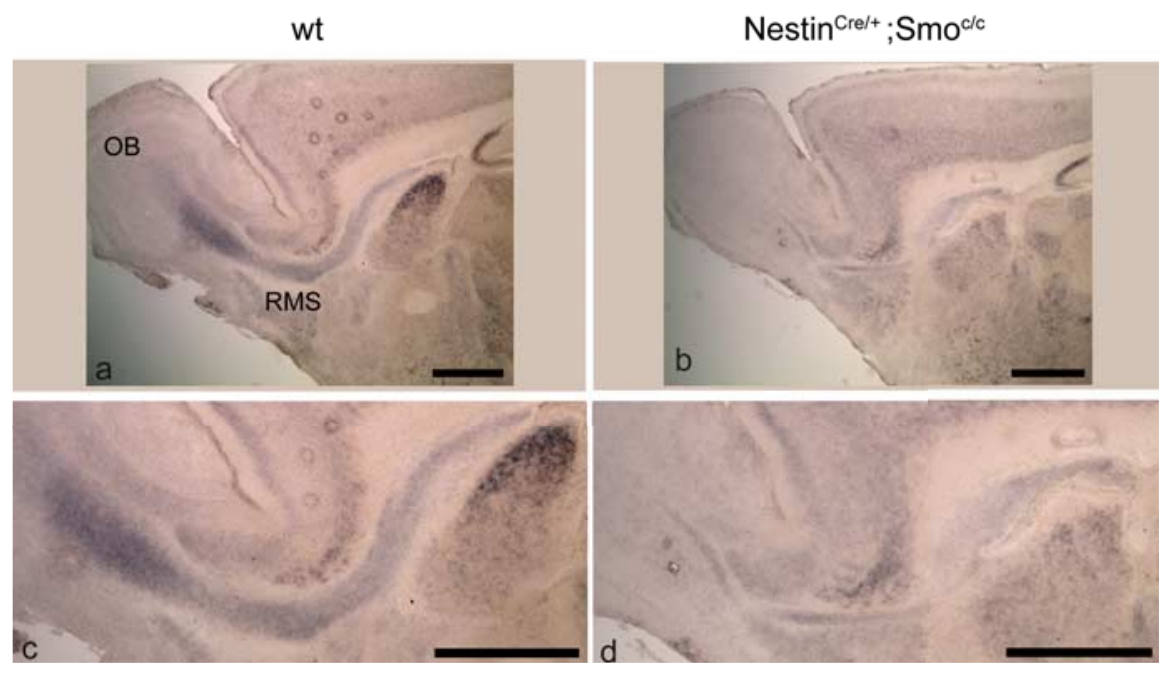

Figure 10. Slit1 expression is markedly decreased in the SVZ and RMS of conditional Smoothened-null mice at P8. $\boldsymbol{a}-\boldsymbol{f}$, Sagittal views of SVZ, RMS, and OB showing in situ hybridization for Slit1 expression in wild-type $(\boldsymbol{a}, \boldsymbol{c})$ and $\mathrm{Nestin}^{\mathrm{Cre} /+} ; \mathrm{Smo}^{\mathrm{c/c}}$ animals $(\boldsymbol{b}$, d) at P8. Scale bars, $200 \mu \mathrm{m}$.

our conditional Smo mutants, we did not detect any abnormality in the morphological appearance of ependymal cilia (supplemental Fig. S4, available at www.jneurosci.org as supplemental material).

Although we observe that the A cell population is extremely affected by the removal of Hh signaling, we did not detect colabeling of Dcx and Glil in wt adult animals (supplemental Fig S2 $h$, available at www.jneurosci.org as supplemental material). The lack of a proximal source of Hh ligand in the vicinity of the A cells would seem to argue that this phenotype is an indirect effect of Hh signaling in B cells. However, it is also possible that longdistance Hh signaling could mediate an effect on A cells through the attenuation of the Gli3 repressor. Indeed, the Gli3 repressor has been implicated as inducing cell death (Litingtung and Chiang, 2000). In addition, in many contexts (Litingtung et al., 2002), most notably in dorsoventral patterning of the telencephalon and dorsoventral midbrain (Rallu et al., 2002; Blaess et al., 2006), Hh functions primarily to attenuate the activity of the Gli3 repressor, rather than to activate $\mathrm{Hh}$ signaling through the production of a Gli activator complex. Because the Hh-mediated removal of the Gli3 repressor can occur in the absence of expression of Gli1 (Rallu et al., 2002), if Hh were acting in this manner in A cells, the absence of Glil expression in this population would not be surprising.

\section{Is $\mathrm{Hh}$ required for both the establishment and maintenance of the adult SVZ stem cell niche?}

Recent analysis using genetic fate mapping of Gli1-expressing lineages demonstrated that this $\mathrm{Hh}$ reporter is first expressed in the B and C cell populations of the SVZ during late embryogenesis (E15.5) (Ahn and Joyner, 2005). This suggests a time frame when the SVZ niche is established and quiescent neural stem cells are set aside. In the present analysis, our use of a Nestin ${ }^{\text {Cre }}$ driver line (Tronche et al., 1999; Graus-Porta et al., 2001) results in the loss of Hh signaling from E12.5 onward (Machold et al., 2003). However, despite the fact that $\mathrm{Hh}$ signaling has been abrogated for the final week of embryogenesis, we observed no obvious effect on the SVZ at birth. This suggests that during the embryonic period from E12.5 until birth, Hh signaling is not required to regulate neural progenitor proliferation. In contrast, during the perinatal period, $\mathrm{Hh}$ seems to be required both to maintain the $B$ cell pool and regulate $C$ cell proliferation. This raises the question of whether Hh signaling is simply needed for the establishment of the adult stem cell niche or whether there is an ongoing requirement for the maintenance of this neural proliferative zone throughout adulthood. To address this question, it will be interesting to remove Hh signaling from the SVZ niche in adult mice to see if it results in the same phenotypes as observed in the present study.

\section{Does Hedgehog signaling act at multiple steps in the stem cell lineage?}

In the present study, the removal of $\mathrm{Hh}$ signaling is done in B cells, at the first step in the stem cell lineage. Our results indicate that the loss of Hh signaling results in multiple abnormalities in the progression of stem cells from their quiescent state to their production of newborn neurons. Are the effects of the loss of Hh signaling a result of its requirement in B cells, or are there sequential iterative roles for $\mathrm{Hh}$ at multiple steps in the SVZ stem cell lineage? To address this issue, it will be interesting to use different driver lines to mediate the removal of Smo in C and A cell lineages specifically. That all actions of Hh signaling are not confined to B cells seems probable, as both the present work and previous findings (Ahn and Joyner, 2005; Palma et al., 2005) have shown that Hh signaling is also activated in $\mathrm{C}$ cells. Moreover, as noted above, in addition to functioning to induce Gli activators, Hh signaling also can mediate the removal of Gli repressors (Wang et al., 2000; Bai et al., 2002, 2004; Fuccillo et al., 2006). Hence, assuming that $\mathrm{Hh}$ signaling is also required in $\mathrm{C}$ cells, one explanation for the differential requirement for $\mathrm{Hh}$ signaling in $\mathrm{B}$ versus $C$ cells is that the levels of Gli activators and/or repressors result in a qualitative difference in the effects of Hh signaling on these two lineages.

Our results demonstrate that coincident with the emergence of the SVZ niche, the loss of Hh signaling has a dramatic effect on neurogenesis in this region. The removal of Smo function results in the rapid and precocious differentiation of $\mathrm{B}$ and $\mathrm{C}$ cells and leads to a transient overproduction of A cells. Paradoxically, this early abundance of A cells does not translate into increased incorporation of interneurons within the perinatal olfactory bulb. To the contrary, we observed a high level of apoptosis of this population before their entry into the RMS. Moreover, we have demonstrated that there is a nonautonomous requirement of $\mathrm{Hh}$ signaling for the migration of A cells, perhaps as a result of the dependence on Hh signaling for the production of Slit1. Clearly, Hh signaling has multiple functions within the stem cell niche.

\section{References}

Ahn S, Joyner AL (2005) In vivo analysis of quiescent adult neural stem cells responding to Sonic hedgehog. Nature 437:894-897.

Anthony TE, Klein C, Fishell G, Heintz N (2004) Radial glia serve as neuronal progenitors in all regions of the central nervous system. Neuron 41:881-890.

Bai CB, Auerbach W, Lee JS, Stephen D, Joyner AL (2002) Gli2, but not Gli1, is required for initial Shh signaling and ectopic activation of the Shh pathway. Development 129:4753-4761 
Bai CB, Stephen D, Joyner AL (2004) All mouse ventral spinal cord patterning by hedgehog is Gli dependent and involves an activator function of Gli3. Dev Cell 6:103-115.

Blaess S, Corrales JD, Joyner AL (2006) Sonic hedgehog regulates Gli activator and repressor functions with spatial and temporal precision in the $\mathrm{mid} / \mathrm{hindbrain}$ region. Development 133:1799-1809.

Britto J, Tannahill D, Keynes R (2002) A critical role for sonic hedgehog signaling in the early expansion of the developing brain. Nat Neurosci 5:103-110.

Brown JP, Couillard-Despres S, Cooper-Kuhn CM, Winkler J, Aigner L, Kuhn HG (2003) Transient expression of doublecortin during adult neurogenesis. J Comp Neurol 467:1-10.

Bulfone A, Kim HJ, Puelles L, Porteus MH, Grippo JF, Rubenstein JL (1993) The mouse Dlx-2 (Tes-1) gene is expressed in spatially restricted domains of the forebrain, face and limbs in midgestation mouse embryos. Mech Dev 40:129-140.

Calaora V, Chazal G, Nielsen PJ, Rougon G, Moreau H (1996) mCD24 expression in the developing mouse brain and in zones of secondary neurogenesis in the adult. Neuroscience 73:581-594.

Capela A, Temple S (2002) LeX/ssea-1 is expressed by adult mouse CNS stem cells, identifying them as nonependymal. Neuron 35:865-875.

Cau E, Gradwohl G, Fode C, Guillemot F (1997) Mash1 activates a cascade of bHLH regulators in olfactory neuron progenitors. Development 124:1611-1621.

Chiang C, Litingtung Y, Lee E, Young KE, Corden JL, Westphal H, Beachy PA (1996) Cyclopia and defective axial patterning in mice lacking Sonic hedgehog gene function. Nature 383:407-413.

Chiasson BJ, Tropepe V, Morshead CM, van der Kooy D (1999) Adult mammalian forebrain ependymal and subependymal cells demonstrate proliferative potential, but only subependymal cells have neural stem cell characteristics. J Neurosci 19:4462-4471.

Corbit KC, Aanstad P, Singla V, Norman AR, Stainier DY, Reiter JF (2005) Vertebrate Smoothened functions at the primary cilium. Nature 437:1018-1021.

Craig CG, Tropepe V, Morshead CM, Reynolds BA, Weiss S, van der Kooy D (1996) In vivo growth factor expansion of endogenous subependymal neural precursor cell populations in the adult mouse brain. J Neurosci 16:2649-2658.

Dahmane N, Ruiz i Altaba A (1999) Sonic hedgehog regulates the growth and patterning of the cerebellum. Development 126:3089-3100.

Doetsch F, Garcia-Verdugo JM, Alvarez-Buylla A (1997) Cellular composition and three-dimensional organization of the subventricular germinal zone in the adult mammalian brain. J Neurosci 17:5046-5061.

Doetsch F, Caille I, Lim DA, Garcia-Verdugo JM, Alvarez-Buylla A (1999a) Subventricular zone astrocytes are neural stem cells in the adult mammalian brain. Cell 97:703-716.

Doetsch F, Garcia-Verdugo JM, Alvarez-Buylla A (1999b) Regeneration of a germinal layer in the adult mammalian brain. Proc Natl Acad Sci USA 96:11619-11624

Doetsch F, Petreanu L, Caille I, Garcia-Verdugo JM, Alvarez-Buylla A (2002) EGF converts transit-amplifying neurogenic precursors in the adult brain into multipotent stem cells. Neuron 36:1021-1034.

Echelard Y, Epstein DJ, St-Jacques B, Shen L, Mohler J, McMahon JA, McMahon AP (1993) Sonic hedgehog, a member of a family of putative signaling molecules, is implicated in the regulation of CNS polarity. Cell 75:1417-1430.

Englund U, Bjorklund A, Wictorin K (2002) Migration patterns and phenotypic differentiation of long-term expanded human neural progenitor cells after transplantation into the adult rat brain. Brain Res Dev Brain Res 134:123-141.

Ericson J, Muhr J, Placzek M, Lints T, Jessell TM, Edlund T (1995) Sonic hedgehog induces the differentiation of ventral forebrain neurons: a common signal for ventral patterning within the neural tube. Cell 81:747-756.

Francis F, Koulakoff A, Boucher D, Chafey P, Schaar B, Vinet MC, Friocourt G, McDonnell N, Reiner O, Kahn A, McConnell SK, Berwald-Netter Y, Denoulet P, Chelly J (1999) Doublecortin is a developmentally regulated, microtubule-associated protein expressed in migrating and differentiating neurons. Neuron 23:247-256.

Fuccillo M, Rallu M, McMahon AP, Fishell G (2004) Temporal requirement for hedgehog signaling in ventral telencephalic patterning. Development 131:5031-5040.

Fuccillo M, Joyner AL, Fishell G (2006) Morphogen to mitogen: the multi- ple roles of hedgehog signaling in vertebrate neural development. Nat Rev Neurosci 7:772-783.

Gleeson JG, Lin PT, Flanagan LA, Walsh CA (1999) Doublecortin is a microtubule-associated protein and is expressed widely by migrating neurons. Neuron 23:257-271.

Graus-Porta D, Blaess S, Senften M, Littlewood-Evans A, Damsky C, Huang Z, Orban P, Klein R, Schittny JC, Muller U (2001) Beta1-class integrins regulate the development of laminae and folia in the cerebral and cerebellar cortex. Neuron 31:367-379.

Haycraft CJ, Banizs B, Aydin-Son Y, Zhang Q, Michaud EJ, Yoder BK (2005) Gli2 and Gli3 localize to cilia and require the intraflagellar transport protein polaris for processing and function. PLoS Genet 1:e53.

Huangfu D, Anderson KV (2005) Cilia and Hedgehog responsiveness in the mouse. Proc Natl Acad Sci USA 102:11325-11330.

Ingham PW, McMahon AP (2001) Hedgehog signaling in animal development: paradigms and principles. Genes Dev 15:3059-3087.

Kinzler KW, Ruppert JM, Bigner SH, Vogelstein B (1988) The GLI gene is a member of the Kruppel family of zinc finger proteins. Nature 332:371-374.

Kohtz JD, Baker DP, Corte G, Fishell G (1998) Regionalization within the mammalian telencephalon is mediated by changes in responsiveness to Sonic Hedgehog. Development 125:5079-5089.

Lai K, Kaspar BK, Gage FH, Schaffer DV (2003) Sonic hedgehog regulates adult neural progenitor proliferation in vitro and in vivo. Nat Neurosci 6:21-27.

Lee J, Platt KA, Censullo P, Ruiz i Altaba A (1997) Glil is a target of Sonic hedgehog that induces ventral neural tube development. Development 124:2537-2552.

Lewis PM, Dunn MP, McMahon JA, Logan M, Martin JF, St-Jacques B, McMahon AP (2001) Cholesterol modification of sonic hedgehog is required for long-range signaling activity and effective modulation of signaling by Ptc1. Cell 105:599-612.

Litingtung Y, Chiang C (2000) Specification of ventral neuron types is mediated by an antagonistic interaction between Shh and Gli3. Nat Neurosci 3:979-985.

Litingtung Y, Dahn RD, Li Y, Fallon JF, Chiang C (2002) Shh and Gli3 are dispensable for limb skeleton formation but regulate digit number and identity. Nature 418:979-983.

Liu A, Wang B, Niswander LA (2005) Mouse intraflagellar transport proteins regulate both the activator and repressor functions of Gli transcription factors. Development 132:3103-3111.

Lois C, Garcia-Verdugo JM, Alvarez-Buylla A (1996) Chain migration of neuronal precursors. Science 271:978-981.

Long F, Zhang XM, Karp S, Yang Y, McMahon AP (2001) Genetic manipulation of hedgehog signaling in the endochondral skeleton reveals a direct role in the regulation of chondrocyte proliferation. Development 128:5099-5108.

Machold R, Hayashi S, Rutlin M, Muzumdar MD, Nery S, Corbin JG, GritliLinde A, Dellovade T, Porter JA, Rubin LL, Dudek H, McMahon AP, Fishell G (2003) Sonic hedgehog is required for progenitor cell maintenance in telencephalic stem cell niches. Neuron 39:937-950.

Marti E, Bumcrot DA, Takada R, McMahon AP (1995) Requirement of 19K form of Sonic hedgehog for induction of distinct ventral cell types in CNS explants. Nature 375:322-325.

May SR, Ashique AM, Karlen M, Wang B, Shen Y, Zarbalis K, Reiter J, Ericson J, Peterson AS (2005) Loss of the retrograde motor for IFT disrupts localization of Smo to cilia and prevents the expression of both activator and repressor functions of Gli. Dev Biol 287:378-389.

McMahon AP, Ingham PW, Tabin CJ (2003) Developmental roles and clinical significance of hedgehog signaling. Curr Top Dev Biol 53:1-114.

Morshead CM, Reynolds BA, Craig CG, McBurney MW, Staines WA, Morassutti D, Weiss S, van der Kooy D (1994) Neural stem cells in the adult mammalian forebrain: a relatively quiescent subpopulation of subependymal cells. Neuron 13:1071-1082.

Nguyen-Ba-Charvet KT, Picard-Riera N, Tessier-Lavigne M, Baron-Van Evercooren A, Sotelo C, Chedotal A (2004) Multiple roles for slits in the control of cell migration in the rostral migratory stream. J Neurosci 24:1497-1506.

Okabe M, Ikawa M, Kominami K, Nakanishi T, Nishimune Y (1997) 'Green mice' as a source of ubiquitous green cells. FEBS Lett 407:313-319.

Palma V, Lim DA, Dahmane N, Sanchez P, Brionne TC, Herzberg CD, Gitton Y, Carleton A, Alvarez-Buylla A, Ruiz i Altaba A (2005) Sonic hedgehog 
controls stem cell behavior in the postnatal and adult brain. Development 132:335-344.

Parras CM, Galli R, Britz O, Soares S, Galichet C, Battiste J, Johnson JE, Nakafuku M, Vescovi A, Guillemot F (2004) Mash1 specifies neurons and oligodendrocytes in the postnatal brain. EMBO J 23:4495-4505.

Rallu M, Machold R, Gaiano N, Corbin JG, McMahon AP, Fishell G (2002) Dorsoventral patterning is established in the telencephalon of mutants lacking both Gli3 and Hedgehog signaling. Development 129:4963-4974.

Rowitch DH, B SJ, Lee SM, Flax JD, Snyder EY, McMahon AP (1999) Sonic hedgehog regulates proliferation and inhibits differentiation of CNS precursor cells. J Neurosci 19:8954-8965.

Sawamoto K, Wichterle H, Gonzalez-Perez O, Cholfin JA, Yamada M, Spassky N, Murcia NS, Garica-Verdugo JM, Marin O, Rubenstein JL, Tessier-Lavigne M, Okano H, Alvarez-Buylla A (2006) New neurons follow the flow of cerebrospinal fluid in the adult brain. Science 311:629-632.

Spassky N, Merkle FT, Flames N, Tramontin AD, Garcia-Verdugo JM, Alvarez-Buylla A (2005) Adult ependymal cells are postmitotic and are derived from radial glial cells during embryogenesis. J Neurosci 25:10-18.

Tronche F, Kellendonk C, Kretz O, Gass P, Anlag K, Orban PC, Bock R, Klein R, Schutz G (1999) Disruption of the glucocorticoid receptor gene in the nervous system results in reduced anxiety. Nat Genet 23:99-103.

Wallace VA (1999) Purkinje-cell-derived Sonic hedgehog regulates granule neuron precursor cell proliferation in the developing mouse cerebellum. Curr Biol 9:445-448.
Wang B, Fallon JF, Beachy PA (2000) Hedgehog-regulated processing of Gli3 produces an anterior/posterior repressor gradient in the developing vertebrate limb. Cell 100:423-434.

Wechsler-Reya RJ, Scott MP (1999) Control of neuronal precursor proliferation in the cerebellum by Sonic Hedgehog. Neuron 22:103-114.

Wichterle H, Garcia-Verdugo JM, Alvarez-Buylla A (1997) Direct evidence for homotypic, glia-independent neuronal migration. Neuron 18:779-791.

Wilkinson DG, Nieto MA (1993) Detection of messenger RNA by in situ hybridization to tissue sections and whole mounts. Methods Enzymol 225:361-373.

Yang HK, Sundholm-Peters NL, Goings GE, Walker AS, Hyland K, Szele FG (2004) Distribution of doublecortin expressing cells near the lateral ventricles in the adult mouse brain. J Neurosci Res 76:282-295.

Yuan W, Zhou L, Chen JH, Wu JY, Rao Y, Ornitz DM (1999) The mouse SLIT family: secreted ligands for ROBO expressed in patterns that suggest a role in morphogenesis and axon guidance. Dev Biol 212:290-306.

Zhang XM, Ramalho-Santos M, McMahon AP (2001) Smoothened mutants reveal redundant roles for Shh and Ihh signaling including regulation of L/R asymmetry by the mouse node. Cell 105:781-792.

Zimmerman L, Parr B, Lendahl U, Cunningham M, McKay R, Gavin B, Mann J, Vassileva G, McMahon A (1994) Independent regulatory elements in the nestin gene direct transgene expression to neural stem cells or muscle precursors. Neuron 12:11-24. 